\title{
INDICATORS OF BIOHYDROCHEMICAL PORTRAIT OF THE WHITE SEA: INTERNAL / EXTERNAL FLUXES OF BIOGENIC SUBSTANCES, BALANCES OF N AND P
}

\author{
A.V. Leonov ${ }^{1}$, L.V. Semenyak ${ }^{2}$, O.V. Chicherina ${ }^{1}$ \\ ${ }^{1}$ Shirshov Institute of Oceanology, Russian Academy of Sciences, \\ 36 Nahimovskiy prospekt, Moscow, 117997, Russia, \\ e-mail:leonov@ocean.ru,ox_stgr@rambler.ru \\ ${ }^{2}$ Russian Federal Research Institute of Fisheries and Oceanography, \\ Verkhnyaya Krasnosel'skaya, 17, Moscow, 107140,Russia,e-mail: lvsemen@yandex.ru_ \\ Submitted 12.09.2018, accepted 30.11.2018
}

\begin{abstract}
On the basis of the average long-term parameters of the marine environment (temperature, light intensity, transparency of water, photoperiod, natural biogenic load and anthropogenic load), the quantitative data were obtained for the characteristics of the biohydrochemical portrait of the White Sea areas using the hydro-ecological CNPSi-model. Main indicators of this portrait are the calculated concentrations of organic and mineral forms of $\mathrm{N}$ and $\mathrm{P}$, the biomass of the organisms of the lower trophic links (heterotrophic bacteria, three groups of phytoplankton, herbivorous and predatory zooplankton) and macrophytes, that change during a year and which participate in the transformation of nutrients. The values of positive and negative internal and external nutrient fluxes that characterize the conditions for the nutrient transformation during a year are also calculated. The task of this study was to obtain information on the annual balances of $\mathrm{N}$ and $\mathrm{P}$ forms on the basis of the calculated values of internal and external nutrient fluxes for different areas and the White Sea as a whole.
\end{abstract}

Keywords: the White Sea ecosystem, biogenic substances, the heterotrophic bacterioplankton, the diatom phytoplankton, the herbivorous and predatory zooplankton, macrophytes, the detritus, trophic chaines, the CNPSi biotransformation model of biogenic substances (BS), the biogeochemical portrait of the White Sea, balance of internal and external $\mathrm{N}$ and $\mathrm{P}$ fluxes for the White Sea and its nine regions

The hydro-ecological CNPSi-model (Leonov, 2012) was used as an instrument for the analyses of oceanological information at the studying of the biotransformation of biogenic substances (BS) in the marine environment in nine regions of the White Sea (1. the Kandalaksha Bay, 2. the Onega Bay, 3. the Dvina Bay, 4. the Mezen' Bay, 5. the Solovetskie Islands, 6. the Basin, 7. the Gorlo, 8. the Voronka, 9. the Chupa Bay) (Leonov et al., 2004, 2005, 2006, 2018). The main forms of $\mathrm{N}$ and P, considered in the CNPSi-model, in this study are: detrital N (ND) and P (PD), dissolved organic N (DON) and P (DOP), mineral forms $\mathrm{P}$ (DIP) and $\mathrm{N}$ (ammonium, nitrite and nitrate $-\mathrm{NH}_{4}, \mathrm{NO}_{2}$ and $\mathrm{NO}_{3}$, respectively), $\mathrm{N}$ of urea (UR) in water environment, as well as mineral components of $\mathrm{N}\left(\mathrm{NH}_{4} \mathrm{~s}\right.$, and $\mathrm{NO}_{3} \mathrm{~s}$ ) and $\mathrm{P}$ (DIPs) in the upper layer of bottom sediments. The conditions for the BS biotransformation are determined by the morphometry of regions, the parameters of the marine environment state (temperature, light intensity, transparency of water, photoperiod, 
natural biogenic load, anthropogenic load), water regime data (atmospheric precipitation, water exchange, river runoff) and activity of «living matter» - organisms of lower trophic links (bacteria, phytoplankton, zooplankton) and macrophytes (Leonov, 2012).

The CNPSi-model reproduces the processes of substance biotransformations on the basis of modern concepts of the BS recycling/turnover: organisms of lower trophic links form their biomass (or the «living matter») with the simultaneous consumption of individual substances, and their metabolite excretions, and detritus formation. These processes affect on the composition of components in marine environments. The following sequence of the behavior and development of organisms is formalized in the CNPSi-model: the heterotrophic bacteria $B 1$ consume detritus and organic fractions of $\mathrm{N}$ and $\mathrm{P}$ in their growth and release of mineral components of $\mathrm{N}$ and $\mathrm{P}$ into the water environment; the phytoplankton $F 1, F 2, F 3$, and macrophytes $M K$ consume consume mineral forms of $\mathrm{N}$ and $\mathrm{P}$, forming a pool of organic substances; the herbivorous herbivorous zooplankton $Z 1$ consumes consumes detritus and phytoplankton, and the predatory zooplankton $Z 2$ consumes detritus and biomasses of bacteria, phytoplankton, herbivorous zooplankton; metabolic excretions of the zooplankton in the form of proportional parts of organic and mineral components of $\mathrm{N}$ and $\mathrm{P}$ support their concentration in the marine environment.

Calculations on the CNPSi-model allow us to identify differences in the conditions of BS biotransformation and in the features of the dynamics of BS concentrations and biomasses of organisms depending on the complex conditions of the marine environment and the peculiarities of the White Sea, in particular. For example, the White Sea is characterized by a decrease in the thickness of the productive layer, a sharp increase in the values of biomass and production of phytoplankton, as well as an increased role of macrophytes production in the BS dynamics (Kuznetsov, 1960). That is why macrophytes $M K$ were introduced into the CNPSi-model as an important biological link in regulating the BS dynamics during a year.

In this study, the results of previous calculations of the intra-annual dynamics of BS concentrations and biomass of organisms participating in their transformation have been partially used (Leonov et al., 2004, 2005, 2006). These calculations allow us to get the first experience in the compile of balances for external and internal fluxes of organic components (DON, ND, DOP and PD) within the different regions of the White Sea (Leonov et al., 2005), and for all BS forms - for the Chupa Bay (Leonov et al., 2006).

In the subsequent calculations, to obtain data on the biohydrochemical portrait of the White Sea, the concentrations of BS in the waters of the main tributaries of the White Sea were refined (by the results of the Hydrometeorological Service and the data from the XVII-XX conferences «Geology of the Seas and Oceans» by measurements of dissolved organic C (DOC), forms of N, and P in the rivers Severnaya Dvina, Onega, Kem' and Mezen' (Leonov et al., 2017, 2018), and also the possible BS inputs to the marine environment with sewage runoff to different regions of the White Sea were estimated.

The adequacy of the calculated data obtained with the help of the CNPSi-model is shown by some facts known from direct observations that characterize the conditions in the development of the diatom phytoplankton $F 1$ dominating in the White Sea (Leonov et al., 2017, 2018): 
- both calculations and observations reflect the features of seasonal changes in BS concentrations (in summer, the most part of $\mathrm{N}$ and $\mathrm{P}$ are represented by organic fractions - their share reaches $80-90 \%$ of their total content);

- the changes in the N-limiting development of $F 1$ occurs both in the water areas of the bays and in the open waters of the White Sea;

- the activity of the $F 1$ vegetation occurs in the first half of April, and the largest their number is recorded in May;

- the correspondence of the estimated and measured rates of biomass $F 1$ growth in the waters of the Chupa Bay (respectively 0.056 and 0.05 day $^{-1}$ ) for summer conditions;

- the aggrement of calculated and measured values of $F 1$ abundance in different surveys in separate years;

- the high degree of conformity of the compared values of the $F 1$ production, evaluated by different ways (measurements were estimated by analytical methods, and calculated values were obtained on the base of BS flux values for $F 1$ estimated with the help CNPSi-model);

- correspondence of primary production (PP) rates: the measured summer rates of PP in the Kandalaksha Bay varied from $7-126$ to $17-374 \mathrm{mg} \mathrm{C} /\left(\mathrm{m}^{2} \times\right.$ day $)$, and the calculated PP rate for this region was $126 \mathrm{mg} \mathrm{C} /\left(\mathrm{m}^{2} \times\right.$ day $)$;

- the correspondence of the annual production rates of $F 1$ in the White Sea: the range of measured values is $1.5-3$ million tons of $C$ for a vegetation period (180 days), and calculated values are $\sim 2.0$ and 3.5 million tons of $\mathrm{C}$ for the considered vegetation periods of 150 and 180 days respectively.

Analysis of the results of the last series of calculations allow us to estimate the values of internal and external fluxes of organic and mineral BS for each month and for a whole year, and then to obtain additional information on the indicators of the biohydrochemical portrait of the sea - the annual balances of the total forms of $\mathrm{N}$ and $\mathrm{P}\left(\mathrm{N}_{\text {tot }}\right.$ and $\left.\mathrm{P}_{\text {tot }}\right)$ for the nine regions and for the White Sea as a whole. These findings are presented and discussed below.

\section{INPUT CONSTITUENTS IN BALANCES OF N AND P}

The positive components of the BS balance in the marine ecosystem are formed by next processes:

- entering of organic and mineral BS to the water environment as a result of vital activity of the community of organisms (their metabolic excretions and detritus formation) at the simultaneous transformations of BS and the formation of «living» biomasses during repeated recycling/turnover of BS;

- receipt of organic and mineral BS with river runoff and with atmospheric precipitations in different regions of the sea;

- BS transfer from neighboring water areas during water exchange through the boundaries of the identified marine regions;

- BS supplies from the Barents Sea to waters of Voronka area of the White Sea; 
- BS input with anthropogenic pollution source (discharged sewage and wastes components) to marine environment;

- additional formation of dissolved organic components (DON and DOP) at the development of the corresponding destruction of suspended $\mathrm{N}$ and $\mathrm{P}$ forms (ND and PD).

The computed data on the annual $\mathrm{N}$ and $\mathrm{P}$ balances are shown in tables 1 and 2, respectively. These values are presented in two dimensions: per unit of the water volume (in $\mathrm{g}$ Element $/\left(\mathrm{m}^{3} \times\right.$ year $)$ ) - to compare the flux values in different regions, and per the total water volume of marine area (each regions and the White Sea as a whole) (in thousand tons of Element) - to have quantitative data on the values of total masses of $\mathrm{N}$ and $\mathrm{P}$ circulating in the marine environment.

\section{Inputs of organic and mineral BS to water environment by vital activities of organisms}

The main stock of BS important for the biochemical potential of sea water is maintained in the marine environment by internal BS recycling and circulation, provided by the metabolic excretory activity of organisms and their formation of detritus.

Organic and mineral components of $\mathrm{N}$ and $\mathrm{P}$, as well as the detritus formed by organisms, are involved in the continuous turnover by marine organisms, they serve as integral additional nutrient components continuously circulating in the common BS pool due to their repeated cycling during the period of the production activity of organisms.

The number of $\mathrm{N}\left(\mathrm{N}_{\text {tot }}\right)$ released by organisms during an year into the water environment is represented in two dimensions: in $\mathrm{g} \mathrm{N} / \mathrm{m}^{3}$ and in thousand tons of $\mathrm{N}$. Then, according to the values of the $\mathrm{N}$ fluxes, the regions of the White Sea can be arranged in the following order: the Dvina Bay $(0.7245,326.0)$ - the Chupa Bay $(0.4646$, $0.5)$ - the Mezen' Bay $(0.4018,23.7)$ - the Onega Bay $(0.3568,48.7)$ - the Kandalaksha Bay $(0.3560,25.3)$ - the Solovetskie Islands $(0.3511,89.8)$ - the Voronka area $(0.3494$, $470.6)$ - the Gorlo area $(0.2859,96.7)$ - the Basin area $(0.1958,78.1)$. The activity of the metabolite excretion by organisms varies considerably through the sea regions. The quota of $\mathrm{N}_{\text {tot }}$ released in $\mathrm{g} \mathrm{N} /\left(\mathrm{m}^{3} \times\right.$ year $)$ in the form of metabolites by the three most active organisms varies widely in the sea regions: the heterotrophic bacteria $B 1 \mathrm{~N}$ has the variation of this fraction in a range of $8.4-37.5 \%$, the herbivorous zooplankton, $\mathrm{Z} 1 \mathrm{~N}$ - in a range of $20.1-38.7 \%$, and macrophytes $M K \mathrm{~N}$ - in a range of $19.8-51.7 \%$. The contribution of other organisms $(F 1 \mathrm{~N}, F 2 \mathrm{~N}, F 3 \mathrm{~N}$, and $Z 2 \mathrm{~N})$ into the $\mathrm{N}_{\text {tot }}$ release is small (or $<5 \%$ ) (Table 1).

The amount of the metabolic release of $\mathrm{N}_{\text {tot }}\left(\mathrm{g} \mathrm{N} /\left(\mathrm{m}^{3} \times\right.\right.$ year $\left.)\right)$ varies among the most active organisms in the following ranges: $M K \mathrm{~N}$ - from 0.0693 to $0.1839, Z 1 \mathrm{~N}-$ from 0.0646 to 0.1765 , and $B 1 \mathrm{~N}$ - from 0.0299 to 0.1637 . $\mathrm{DON}, \mathrm{NH}_{4}$ and UR are the main components of metabolic excretions of organisms in the total mass of $\mathrm{N}_{\text {tot }}$. At the same time, the share of major components allocated for a year and their quantity varies among organisms in different marine areas. In the zooplankton $Z 1 \mathrm{~N}$, the fraction of DON released is $80 \%$ of $\mathrm{N}_{\text {tot }}$ (among sea areas, the amount of DON released varies within 


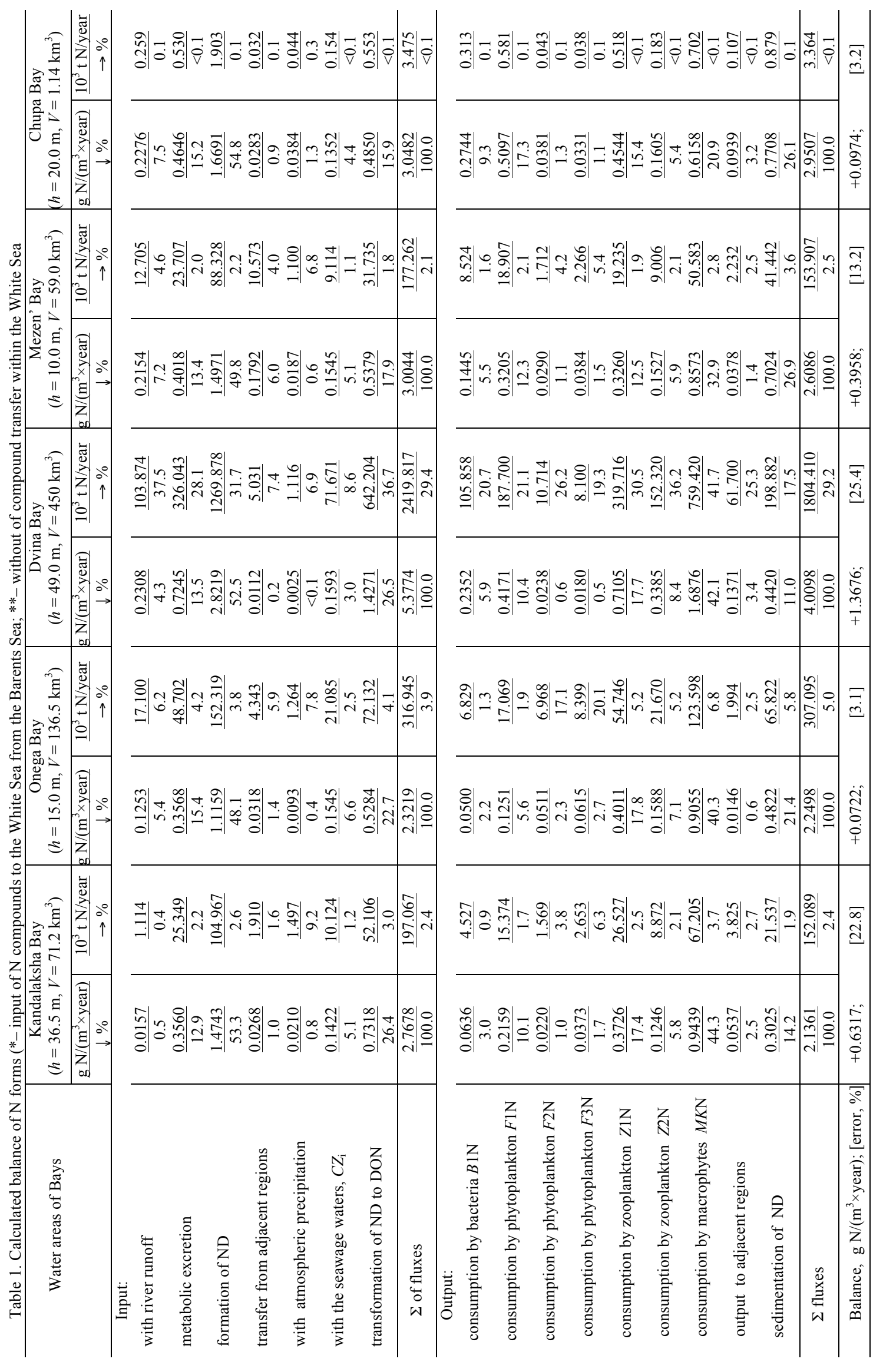


Океанологические исследования. 2018. Том 46. № 3. С. 144-182

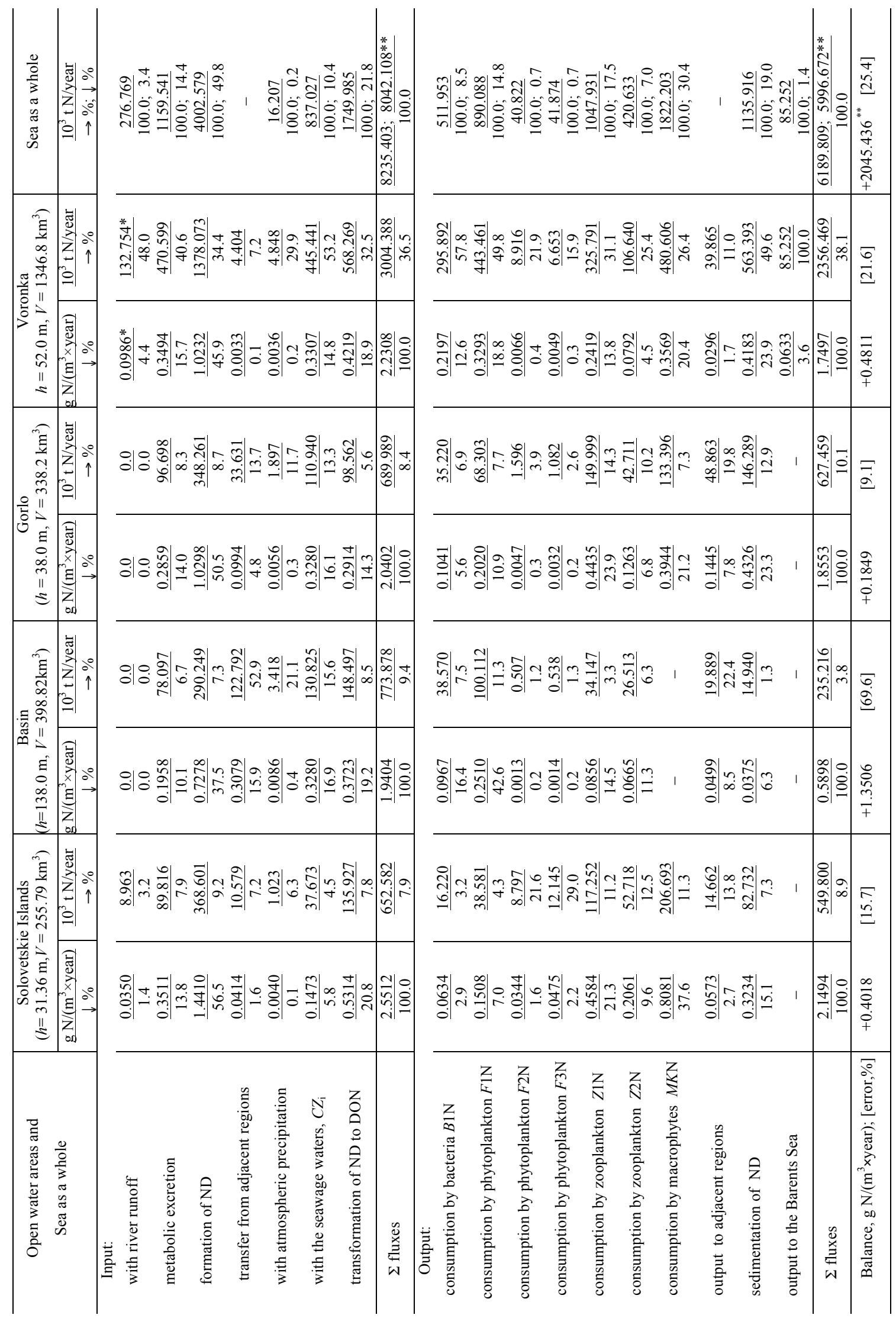




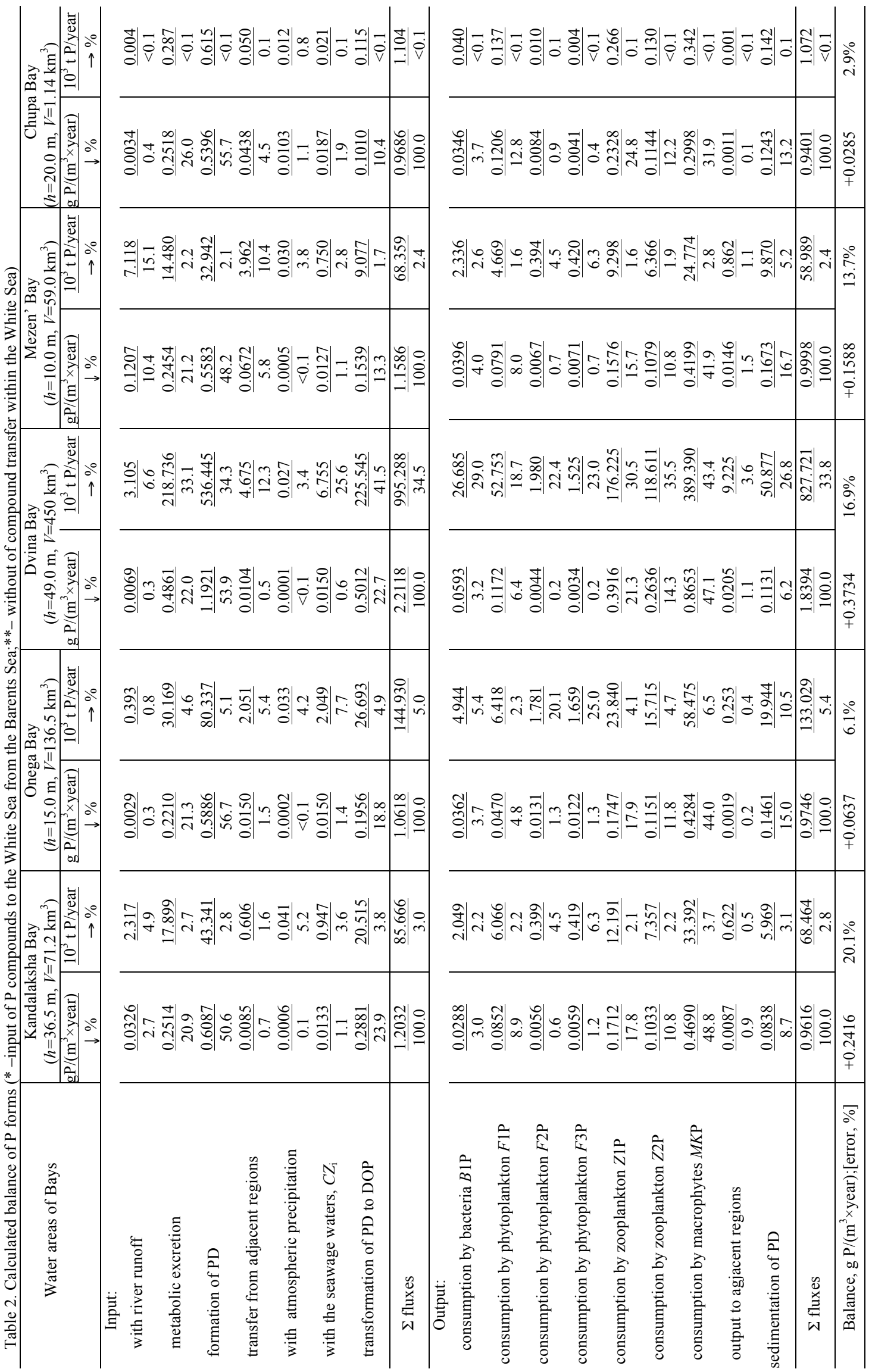


Океанологические исследования. 2018. Том 46. № 3. С. 144-182

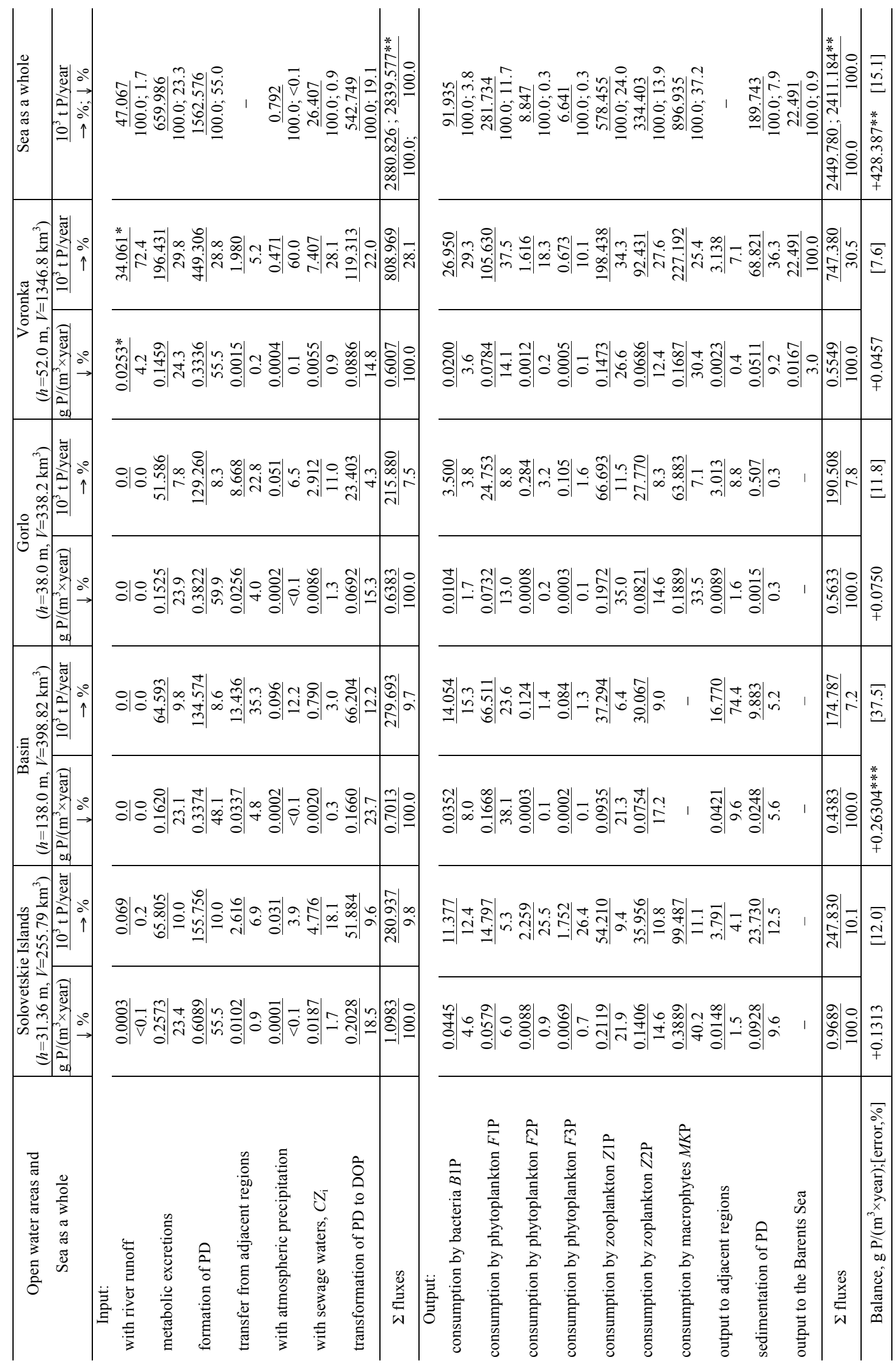


0.0606-0.1412 $\mathrm{g} \mathrm{N} /\left(\mathrm{m}^{3} \times\right.$ year $\left.)\right)$, in macrophytes $M K \mathrm{~N}$, this fraction is lower (65\%) with fluctuations in DON released in sea areas from 0.0451 to $0.2172 \mathrm{~g} \mathrm{~N} /\left(\mathrm{m}^{3} \times\right.$ year $)$, and in the heterotrophic bacteria $B 1 \mathrm{~N}$ this proportion is even lower $(55 \%)$, and the fluctuation of DON released by the bacteria is $0.0165-0.0900 \mathrm{~g} \mathrm{~N} /\left(\mathrm{m}^{3} \times\right.$ year $)$.

Ammonium $\mathrm{N}\left(\mathrm{NH}_{4}\right)$ is the second most important metabolic product. In heterotrophic bacteria $B 1 \mathrm{~N}$, its share in the release is $30 \%$ of $\mathrm{N}_{\text {tot }}$, which corresponds to annual $\mathrm{NH}_{4}$ excretion, varying in the sea areas within $0.0090-0.0491 \mathrm{~g} \mathrm{~N} /\left(\mathrm{m}^{3} \times\right.$ year $)$. In macrophytes $M K \mathrm{~N}$ and zooplankton $Z 1 \mathrm{~N}$, the fraction of released $\mathrm{NH}_{4}$ is only $5 \%$ of $\mathrm{N}_{\text {tot }}$ and therefore it is not evaluated here. The second most important metabolite is UR: its share in $M K \mathrm{~N}$ and $Z 1 \mathrm{~N}$ is 30 and $15 \%$ of $\mathrm{N}_{\text {tot }}$, respectively. The total amount of UR released into the water in different marine regions fluctuates in macrophytes $M K \mathrm{~N}$ and zooplankton $Z 1 \mathrm{~N}$, respectively, within $0.0208-0.1002$ and $0.0114-0.0265 \mathrm{~g} \mathrm{~N} /\left(\mathrm{m}^{3} \times\right.$ year $)$. In bacteria $B 1 \mathrm{~N}$, the fraction of UR in the excretions is small $\left(15 \%\right.$ of $\left.\mathrm{N}_{\text {tot }}\right)$, and the range of fluctuations of the UR among the sea regions is $0.0045-0.0245 \mathrm{~g} \mathrm{~N} /\left(\mathrm{m}^{3} \times\right.$ year $)$.

On the unit of water volume, the smallest values of the N-containing products released by the the bacteria $B 1 \mathrm{~N}$, the zooplankton $Z 1 \mathrm{~N}$ and macrophytes $M K \mathrm{~N}$ are noted in different regions (respectively in the Onega Bay, the Basin and the Voronka), and the largest ones are in the Dvina Bay (bacteria have also increased the release of N-containing metabolites in the waters of the Chupa Bay) (Table 1).

By the amount of the metabolic total $\mathrm{P}\left(\mathrm{P}_{\text {tot }}\right)$ released per year (in two dimensions $-\mathrm{g} \mathrm{P} / \mathrm{m}^{3}$ and thousand tons of $\left.\mathrm{P}\right)$, the White Sea regions can be arranged in the following sequence: the Dvina Bay $(0.4861,218.7)$ - the Solovetskie Islands $(0.2573,65.8)$ - the Chupa Bay $(0.2518,0.3)$ - the Kandalaksha Bay $(0.2514,17.9)$ - the Mezen' Bay $(0.2454$, $14.5)$ - the Onega Bay $(0.2210,30.2)$ - the Basin $(0.1620,64.5)$ - the Gorlo $(0.1525,51.6)$ - the Voronka $(0.1459,196.5)$. The share of $\mathrm{P}_{\text {tot }}$, calculated in the form of metabolites in $\mathrm{g} \mathrm{P} /\left(\mathrm{m}^{3} \times\right.$ year$)$, varies for different sea regions in the most active groups of organisms within the range: $5.0-11.9 \%$ in the bacteria $B 1 \mathrm{P}, 9.7-40.8 \%$ in the diatom phytoplankton $F 1 \mathrm{P}, 23.5-42.3 \%$ - in the herbivorous zooplankton $Z 1 \mathrm{P}$, and $29.6-47.7 \%$ in macrophytes MKP. The contribution of other organisms, F2P, F3P and Z2P, to metabolic excretions of $\mathrm{P}_{\text {tot }}$ is $<3 \%$ and therefore is not discussed here (Table 2).

Among the sea regions, the metabolic excretions of $\mathrm{P}_{\text {tot }}$ (in $\mathrm{g} \mathrm{P} /\left(\mathrm{m}^{3} \times\right.$ year $)$ ) vary from 0.0432 to 0.2251 in macrophytes $M K \mathrm{P}$, from 0.0529 to 0.1407 in the zooplankton $Z 1 \mathrm{P}$, from 0.0238 to 0.0660 in the phytoplankton $F 1$ P, and from 0.0076 to 0.0438 in the bacteria $B 1 \mathrm{~N}$. DOP and DIP are the main components of metabolic excretions in the whole mass of $\mathrm{P}_{\text {tot }}$. Their proportions in the general amount of $\mathrm{P}_{\text {tot }}$ vary in organisms: in the bacteria $B 1 \mathrm{P}$ - the ratios of DOP and DIP are $80 \%$ and $20 \%$, respectively; in the phytoplankton $F 1 \mathrm{P}-60$ and $40 \%$ of $\mathrm{P}_{\text {tot }}$; in the zooplankton $Z 1 \mathrm{P}-50$ and $50 \%$ of $\mathrm{P}_{\text {tot }}$; in macrophytes $M K \mathrm{P}-80$ and $20 \%$ of $\mathrm{P}_{\text {tot }}$. In the sea regions, the amount of DOP, released by the bacteria $B 1 \mathrm{P}$, varies between $0.0061-0.0350 \mathrm{~g} \mathrm{P} /\left(\mathrm{m}^{3} \times\right.$ year $\left.)\right)$; in the phytoplankton $F 1 \mathrm{P}$, this range is $0.0238-0.0378$, in the zooplankton Z1P - 0.0265-0.0704, in macrophytes $M K \mathrm{P}-0.0346-$ $0.1801 \mathrm{~g} \mathrm{P} /\left(\mathrm{m}^{3} \times\right.$ year $)$. The amount of DIP, released as metabolites by the bacteria $B 1 \mathrm{P}$, varies in the sea regions in the range $0.0015-0.0088 \mathrm{~g} \mathrm{P} /\left(\mathrm{m}^{3} \times\right.$ year $)$; in the phytoplankton 
$F 1 \mathrm{P}$ this range is $0.0095-0.0247$; in the zooplankton $Z 1 \mathrm{P}$ it is $0.0265-0.0704$, and in macrophytes $M K \mathrm{P}-0.0096-0.0450 \mathrm{~g} \mathrm{P} /\left(\mathrm{m}^{3} \times\right.$ year $)$. Among the sea regions, the lowest values of $\mathrm{P}$-containing components released by the bacteria $B 1 \mathrm{P}$ are noted for Gorlo; by the phytoplankton $F 1 \mathrm{P}$ - Onega Bay, by the zooplankton Z1P and macrophytes $M K \mathrm{P}$ region of Voronka. The greatest release of P-containing substrates is recorded mainly in the Dvina Bay, but the increased release of DOP and DIP by the phytoplankton F1P occurs also in the waters of the Chupa Bay and the Basin.

The formation of detritus, including particulate forms of $\mathrm{N}(\mathrm{ND})$ and $\mathrm{P}$ (PD), serves as a significant internal resource for replenishing BS in the marine environment. Detritus includes the dead biomass of organisms of the whole community involved in the transformation of $\mathrm{N}$ and $\mathrm{P}$ compounds. According to the amount of ND formed per year (and calculated in $\mathrm{g} \mathrm{N} / \mathrm{m}^{3}$ and in thousand tons of $\mathrm{N}$ ), the White Sea regions form the following series: the Dvina Bay $(2.8220,1269.9)$ - the Chupa Bay $(1.6691,1.9)$ - the Mezen' Bay $(1.4971,88.3)$ - the Kandalaksha Bay $(1.4743,105.0)$ - the Solovetskie Islands $(1.4410,368.6)$ - the Onega Bay $(1.1159,152.3)$ - the Gorlo $(1.0298,348.3)-$ the Voronka $(1.0232,1378.1)$ - the Basin $(0.7278,290.3)$. The share of ND, calculated in $\mathrm{g} \mathrm{N} /\left(\mathrm{m}^{3} \times\right.$ year$)$, accounts from 37.5 to $56.5 \%$ of total $\mathrm{N}$ receipts from the considered external and internal sources (the smallest part characterizes the Basin area, and the largest one - the region of the Solovetskie Islands) (Table 2).

The most significant contribution to the formation of detritus ND is made by the diatom phytoplankton $F 1 \mathrm{~N}$, two groups of zooplankton $(Z 1 \mathrm{~N}$ and $Z 2 \mathrm{~N})$, as well as macrophytes $M K \mathrm{~N}$. The contribution of these organisms to $\mathrm{ND}$, estimated in $\mathrm{g} \mathrm{N} /\left(\mathrm{m}^{3} \times\right.$ year $)$, varies among the sea regions: in the phytoplankton $F 1 \mathrm{~N}$ it is between $7.3-$ $24.9 \%$, in zooplankton ( $\mathrm{Z} 1 \mathrm{~N}, \mathrm{Z} 2 \mathrm{~N})$ and macrophytes $M K \mathrm{~N}$ - these ranges are 3.4-41.7, $12.1-33.4$, and $26.3-62.8 \%$, respectively. The smallest contribution to the formation of ND by the phytoplankton $F 1 \mathrm{~N}$ was noted for the region of the Solovetskie Islands, by the zooplankton $Z 1 \mathrm{~N}$ - in the Onega Bay, by the zooplankton $Z 2 \mathrm{~N}$ - in the Chupa Bay, by macrophytes $M K \mathrm{~N}$ - in the region of the Voronka. The largest contribution of the phytoplankton $F 1 \mathrm{~N}$ to the formation of ND is recorded in the waters of the Chupa Bay, by zooplankton $\mathrm{Z} 1 \mathrm{~N}$ and $\mathrm{Z} 2 \mathrm{~N}$ - in the waters of the Basin, and by macrophytes $M K \mathrm{~N}$ in the waters of the Onega Bay.

Formed for the year, the general mass of PD (in $\mathrm{g} \mathrm{P} / \mathrm{m}^{3}$ and in thousand tons of $\mathrm{P}$ ) in the regions of the White Sea can be traced in the following series: the Dvina Bay (1.1921, $536.4)$ - the Solovetskie Islands $(0.6089,155.8)$ - the Kandalaksha Bay $(0.6087,43.3)$ the Onega Bay $(0.5886,80.3)$ - the Mezen' Bay $(0.5583,32.9)$ - the Chupa Bay $(0.5396$, $0.6)$ - the Gorlo $(0.3822,129.3)$ - the Basin $(0.3374,134.6)$ - the Voronka $(0.3336$, 449.4). The share of the generated $\mathrm{PD}$, calculated in $\mathrm{g} \mathrm{P} /\left(\mathrm{m}^{3} \times\right.$ year $)$, is $48.1-59.9 \%$ of all recorded $\mathrm{P}$ inputs from external and internal sources (the smallest is in the Basin, and the largest is in the Gorlo).

A significant contribution to the formation of $\mathrm{PD}$, estimated in $\mathrm{g} \mathrm{P} /\left(\mathrm{m}^{3} \times\right.$ year $)$, is made by the diatom phytoplankton $F 1 \mathrm{P}$, two groups of zooplankton (Z1P and Z2P), and macrophytes $M K \mathrm{P}$. For the sea regions, the contribution of these organisms to the total 
PD pool varies significantly: for $F 1 \mathrm{P}$ - in the range $2.9-19.8 \%$, for $\mathrm{Z} 1 \mathrm{~N}, \mathrm{Z} 2 \mathrm{~N}$ and $M K \mathrm{~N}-$ these ranges are 20.7-39.4, 16.1-39.7, and 34.8-55.9\%, respectively. The smallest amount of PD is formed by the phytoplankton F1P in the Onega Bay, by the zooplankton Z1P in the Mezen' Bay, by the zooplankton Z2P - in the Kandalaksha Bay, by macrophytes $M K \mathrm{P}$ - in the region of the Voronka. The greatest amount of PD is formed by the phytoplankton $F 1 \mathrm{P}$, zooplankton $Z 1 \mathrm{~N}$, and $Z 2 \mathrm{~N}$ in the waters of the Basin, and by macrophytes $M K \mathrm{P}$ - in the waters of the Kandalaksha Bay.

\section{Input of BS to sea waters with river flow}

Among the numerous tributaries of the White Sea, the main ones are identified, their runoff maintains the water balance and ensures the flow of organic and mineral BS to selected areas of the sea: in the Kandalaksha Bay - the Niva River, in the Onega Bay the Onega River, in the Dvina Bay - the Northern Dvina River, in the Mezen' Bay - the Mezen' River, in the Solovetskie Islands - the Kem' River, in the Chupa Bay - the Keret' River. The average annual freshwater flow of rivers in the White Sea is according to various estimates - from 180-189 to 200-220 km³ (Oceanographic conditions ..., 1991; Tolstikov, 2016). It provides not less than $88 \%$ of fresh water intake to the sea (Elisov, 1997). The maximum river flow occurs in the spring during the flood period (in MayJune, $40-50 \%$ of the annual runoff occurs), and the minimum runoff is in FebruaryMarch (Zalogin, Kosarev, 1999). River runoff brings to the White Sea 48 million tons of solid particles, $\sim 25$ million tons of mineral and 5-6 million tons of organic solutes (Neveski et al., 1977).

River runoff determines the conditions for seasonal desalination of the surface waters of the White Sea and serves as the main source of pollution of the White Sea, as rivers carry to the coastal waters the polluted substances from enterprises of the pulp and paper industry, the Ministry of Energy, housing and communal services, vessels of river and marine fleet (Kotova et al., 2016). Therefore, the water areas of river mouths undergo the maximum anthropogenic influence (Tolstikov, 2016).

An increase in the inter- and intra-annual variability of the concentrations of N- and P-compounds were noted with increasing load on the rivers of the White Sea basin (Bryzgalo, Ivanov, 2002). With the regime of rivers flowing into the White Sea, the significant intra-annual variability of runoff and outflow of BS into the sea regions is associated. The greater the load in the sea area for the removal of BS, the higher the dispersion values of their concentrations (Lisitsyn, 2010).

The flux of BS into the marine environment with the river runoff $\left(R_{\mathrm{Cin}}\right)$ is calculated in the CNPSi-model by the equation:

$$
R_{\text {Cin }}=Q W \text { in }(i, j) \times C \text { in }(k, i) / V(i, j), \text { g Element } /\left(\mathrm{m}^{3} \times \text { month }\right),
$$

where $i, j, k$ are the CNPSi-model counters for the selected water areas $(i=9)$, layers $(j=1)$ and components $(k=29)$; $Q W$ in $(i, j)$ - water flow at the outer boundaries of the tributaries 
in the relevant sea area, $\mathrm{km}^{3} /$ month; $C$ in $(k, i)$ is the average monthly concentration of the considered BS in the inflowing waters entering the studied area of the sea, mg Element/L; $V(i, j)$ is the volume of water in the considered sea area, $\mathrm{km}^{3}$. To estimate the annual flux of BS with river runoff to the studied area of the sea, the $R_{\text {Cin }}$ values computed for each month are added. The actual flux of BS with river water depends on the ratio of water discharge of the river to the volume of sea water in the area under consideration. As a rule, for most months these rations are small, only in May-June (during the flood period) they are increased.

In different regions of the White Sea, the annual BS input with the river runoff is significantly various. For example, fluctuations in the arrival of $\mathrm{P}_{\text {tot }}$ are within the limits of values exceeding 400 times $\left(0.0003-0.1207 \mathrm{~g} \mathrm{P} /\left(\mathrm{m}^{3} \times\right.\right.$ year) (Table 2$)$, the difference in $\mathrm{N}_{\text {tot }}$ is much less (in 6.6 times $-0.0350-0.2308 \mathrm{~g} \mathrm{~N} /\left(\mathrm{m}^{3} \times\right.$ year) (Table 1$)$.

There is a significant difference in river runoff and its input of individual fractions of biogenic elements in the White Sea water area. For example, the greatest input of DIP with runoff of the Niva River is $0.0316 \mathrm{~g} \mathrm{P} /\left(\mathrm{m}^{3} \times\right.$ year $)$ or 2.3 thousand $\mathrm{t}$ of $\mathrm{P}$, while a very small amount of DIP (from 0.0002 to $0.0044 \mathrm{~g} \mathrm{P} /\left(\mathrm{m}^{3} \times\right.$ year)) is to other regions of the sea. Input of DOP with river runoff is increased into the waters of the Mezen' Bay $\left(0.1145 \mathrm{~g} \mathrm{P} /\left(\mathrm{m}^{3} \times\right.\right.$ year $), 6.8$ thousand tons of $\left.\mathrm{P}\right)$. For other areas it is in low ranges 0.0001-0.0021 g P/(m³ $\times$ year). In the waters of the Onega and Mezen' bays, the input of $\mathrm{PD}$ with river runoff is respectively 0.0025 and $0.0018 \mathrm{~g} \mathrm{P} /\left(\mathrm{m}^{3} \times\right.$ year) (or 0.3 and 0.1 thousand tons of $\mathrm{P}$ ), while in other areas of the White Sea it is lower (within $<0.0001-$ $0.0013 \mathrm{~g} \mathrm{P} /\left(\mathrm{m}^{3} \times\right.$ year $\left.)\right)$.

The greatest income of $\mathrm{N}_{\text {tot }}$ with river runoff occurs in the waters of the Dvina, Chupa, and Mezen' Bays (respectively 0.2308, 0.2276 and $0.2155 \mathrm{~g} \mathrm{~N} /\left(\mathrm{m}^{3} \times\right.$ year) or $103.9,0.3$, and 12.7 thousand tons of $\mathrm{N})$, and the smallest amount - in the waters of the Kandalaksha Bay $\left(0.0157 \mathrm{~g} \mathrm{~N} /\left(\mathrm{m}^{3} \times\right.\right.$ year $), 1.1$ thousand tons of $\left.\mathrm{N}\right)$ (Table 1$)$. Input of DON and $\mathrm{NO}_{3}$ with river runoff is increased to the Dvina Bay (respectively 0.1705 and $0.0129 \mathrm{~g} \mathrm{~N} /\left(\mathrm{m}^{3} \times\right.$ year) or 51.5 and 5.8 thousand tons of $\left.\mathrm{N}\right)$. Inputs of $\mathrm{DON}, \mathrm{NH}_{4}$ and UR to the waters of the Mezen' Bay with river runoff are $0.1145,0.0520$ and 0.0231 $\mathrm{g} \mathrm{N} /\left(\mathrm{m}^{3} \times\right.$ year) or $6.8,3.1,1.4$ thousand tons of $\mathrm{N}$, respectively. Inputs of $\mathrm{ND}, \mathrm{NH}_{4}, \mathrm{NO}_{3}$ and UR to the Chupa Bay waters with river runoff are respectively 0.0529, 0.0847, 0.0156 and $0.0388 \mathrm{~g} \mathrm{~N} /\left(\mathrm{m}^{3} \times\right.$ year $)$ or $0.1,0.1,0.02$ and 0.04 thousand $\mathrm{t}$ of $\mathrm{N}$.

Water flow of the Northern Dvina River is the largest (it accounts for $69.3 \%$ of the total water flow of the rivers surveyed and $63.9-84.8 \%$ of the various BS inputs). The shares of BS inputs with the river flows of Onega, Mezen, Niva and Kem' are respectively 3.8-13.7, 6.3-22.5, 1.2-5.3, and 9.4-6.2\% of the total mass of BS, calculated in g Element/ $\left(\mathrm{m}^{3} \times\right.$ year). In May-June, when the river runoff of the Northern Dvina River is the largest, and the share of annual inputs of a number of BS in the sea is also increased, in particular DIP to $45 \%$, DOP and PD to $76.6 \%$, DOC, DON and ND to $53.8 \%$, DISi to $43.6 \%, \mathrm{O}_{2}$ to $50.2 \%$. Increased input of $\mathrm{NH}_{4}$ by waters of the Northern Dvina to the Dvina Bay is in April (11.6\%), July (19.8\%), and September (31.7\%), $\mathrm{NO}_{2}-$ in January (10.8\%), MayJune (39.0\%), and December (13.6\%), $\mathrm{NO}_{3}$ - in January-March (27.6\%), and April-May (52.4\%) (Leonov, Chicherina, 2004; Leonov et al., 2018). 


\section{Input of BS with atmospheric precipitations}

In comparison with river runoff, the ratio of moisture entering the studied marine area with atmospheric precipitation to the volumes of the upper layer water is much lower. In the CNPSi-model, the calculations of the BS input rates to the marine environment with atmospheric moisture $\left(A_{\mathrm{C}(\mathrm{r})}\right)$ are performed using the equation:

$$
A_{\mathrm{C}(\mathrm{r})}=f l(k) \times(Q \mathrm{pr} / V(i)) \times C(r), \mathrm{g} \text { Element } /\left(\mathrm{m}^{3} \times \text { months }\right)
$$

where $Q \mathrm{pr}$ - monthly values of the atmospheric precipitation, $\mathrm{km}^{3} /$ month; $V(i)$ - water volume in the studied marine area, $\mathrm{km}^{3} ; C(\mathrm{r})$ is the average annual concentration of BS (ND, DON, $\left.\mathrm{NH}_{4}, \mathrm{NO}_{2}, \mathrm{NO}_{3}, \mathrm{PD}, \mathrm{DOP}, \mathrm{DIP}\right)$ in atmospheric moisture, mg Element/L; $f l(k)$ is a parameter for regulating the transfer of BS by the water flow $(C(\mathrm{r})$ participates in the transfer at $f l(k)=1$, and does not participate with $f l(k)=0)$. The values of $A_{\mathrm{C}(\mathrm{r})}$ are calculated for each month, and they are summed up when calculating the annual arrival of BS in the studied marine area.

The amount of atmospheric precipitation varies in the regions of the White Sea: it is the smallest in the middle part of the Voronka area and in the Basin $(<300 \mathrm{~mm})$, near the coast it increases to $450-500 \mathrm{~mm}$, and it is the largest - in the Dvina and Onega bays (500-600 mm). In summer and autumn (June-October), the amount of precipitation is greatest. In the northern part of the Voronka, the greatest precipitation $(50-75 \mathrm{~mm})$ is in October, in other regions - in September (due to the greatest cyclonic activity in these months). The smallest precipitation (15-24 mm/month) is recorded at the end of winterearly spring (February-March) with a decrease in cyclonic activity in these months. Only in the northern part of the Voronka the smallest precipitation $(19 \mathrm{~mm})$ is in April. This feature is for waters bordering with the ocean areas, characterized by the continental type of annual distribution of atmospheric precipitation. For the warm period of the year (April-October), the quota of precipitation is $60-75 \%$ of annual one, and for the cold season $-25-30 \%$. In the form of rain, precipitation dominates in June-September (41-53\% of annual precipitation). Precipitation in the form of snow makes up 25-46\%, mixed precipitation accounts for 13-20\% of annual precipitation (Leonov et al., 2004). The average content of BS in atmospheric moisture was taken from the data given in (Meybeck, 1982).

The $\mathrm{N}_{\text {tot }}$ annual input with atmospheric precipitation in the regions of the White Sea is $0.0025-0.0384 \mathrm{~g} \mathrm{~N} / \mathrm{m}^{3}$ (total for the sea as a whole -16.207 thousand tons of $\mathrm{N}$, or $0.2 \%$ of the $\mathrm{N}_{\text {tot }}$ input); in the form of $\mathrm{DON}$ and $\mathrm{NO}_{3}$ comes to regions of $18 \%$, ND and $\mathrm{NH}_{4}$ - respectively 36 and $27 \%$. The annual input of $\mathrm{P}_{\text {tot }}$ is $0.0001-0.0104 \mathrm{~g} \mathrm{P} / \mathrm{m}^{3}$ (in the sum for the sea -0.792 thousand tons of $\mathrm{P}$, or $<0.1 \%$ ); in regions $1-7$ and 9 , the inputs of DOP, DIP and PD with atmospheric precipitation are respectively $33.3 \%$, and for the Voronka area - DOP and DIP for $8.6 \%$ and PD for $82.8 \%$. 


\section{Transfer of BS at the water exchange through the boundaries of regions}

Water exchange across the boundaries of the selected areas of the White Sea and the Barents Sea smooths possible gradients of the substance concentrations in neighboring marine areas and serves as a natural mechanism for supporting concentrations of BS at insufficient their inputs from external sources. The intensity of BS input at the water exchange is determined not only by the number of water-borne areas transported across region boundaries, but also by differences in BS concentrations in neighboring water areas between which water exchange takes place. Calculations show that the role of water exchange, as a source of replenishment of the $\mathrm{N}_{\text {tot }}$ and $\mathrm{P}_{\text {tot }}$ concentrations, differs significantly in the regions of the White Sea. The relative contribution of water exchange as a source of replenishment of $\mathrm{N}_{\text {tot }}$ and $\mathrm{P}_{\text {tot }}$ varies according to the sea areas, respectively, within $0.1-$ $15.9 \%$ and $0.2-5.8 \%$ (the smallest contribution is typical for the Voronka region, and the largest contribution is in the Basin (for $\mathrm{N}_{\text {tot }}$ ) and in the Mezen' Bay (for $\mathrm{P}_{\text {tot }}$ ).

The total amount of $\mathrm{N}_{\text {tot }}$ transported by the water masses in the regions of the White Sea varies considerably. The sea areas according to the water exchange $\mathrm{N}_{\text {tot }}$, calculated in $\mathrm{g} \mathrm{N} /\left(\mathrm{m}^{3} \times\right.$ year $)$ and in thousand tons of $\mathrm{N}$, can be arranged in the following order: the Basin $(0.3079,122.8)$ - the Mezen' Bay $(0.1792,10.6)$ - the Gorlo $(0.0994,33.6)$ - the Solovetskie Islands $(0.0414,10.6)$ - the Onega Bay $(0.0318,4.3)$ - the Chupa Bay $(0.0283$, $0.03)$ - the Kandalaksha Bay $(0.0268,1.9)$ - the Dvina Bay $(0.0112,5.04)$ - the Voronka $(0.0033,4.4)$ (Table 1$)$. According to the water supply of $\mathrm{P}_{\text {tot }}\left(\mathrm{g} \mathrm{P} /\left(\mathrm{m}^{3} \times\right.\right.$ year $)$ and thousand tons of $\mathrm{P})$, the sea areas can be arranged in the following row: the Mezen' Bay $(0.0672$, $4.0)$ - the Chupa Bay $(0.0438,0.05)$ - the Basin $(0.0337,13.4)$ - the Gorlo $(0.0256$, $8.7)$ - the Onega Bay $(0.0150,2.0)$ - the Dvina Bay $(0.0104,4.7)$ - the Solovetskie Islands $(0.0102,2.6)$ - the Kandalaksha Bay $(0.0085,0.6)$ - the Voronka $(0.0015,2.0)$ (Table 2). The smallest contribution of water exchange in the input of $\mathrm{N}_{\text {tot }}$ and $\mathrm{P}_{\text {tot }}$, calculated in $\mathrm{g}$ Element/( $\mathrm{m}^{3} \times$ year), was obtained for the Voronka area, and the largest for the Basin (according to $\mathrm{N}_{\text {tot }}$ ) and the Mezen' Bay (according to $\mathrm{P}_{\text {tot }}$ ). The share of the substances transport as a source of replenishment of biogenic elements varies for different regions of the sea: according to $\mathrm{N}_{\text {tot }}$ in the range of $0.2-15.9 \%$ (it is the lowest for the Dvina Bay and the largest for the Basin), and for $\mathrm{P}_{\text {tot }}$ - the range of fluctuations is $0.2-5.8 \%$ (the smallest share is for the Voronka area and the largest for the Mezen' Bay).

An important feature of water exchange, as a mechanism of natural replenishment of BS stocks, is the unequal participation of $\mathrm{N}$ and $\mathrm{P}$ chemical and biological variables in the sea areas in the spatial transport of water masses between different water regions. When calculating the CNPSi-model for each variable (chemical and biological), the amount of substances transferred by the water masses at each time step was calculated separately for water exchange for each area. Then these quantities were added to obtain information on the transfer of substances for each month and year for all areas. The basic chemical forms of N, actively involved in transport by the water masses, are DON and ND (the transfer of mineral forms of $\mathrm{N}$ due to low concentrations is negligible). 
The relative contribution to the DON transport by the water masses, estimated in $\mathrm{g} \mathrm{N} /\left(\mathrm{m}^{3} \times\right.$ year$)$, in regions $1-9$ is correspondingly $60.6,18.8,50.4,31.5,50.0,29.6,38.2$, 2.2 , and $48.7 \%$. The contribution to the ND transfer for the specified areas gives the following values: $22.1,60.9,30.1,60.4,22.4,47.7,47.5,7.6$, and $21.6 \%$. The relative contribution of the transferred total biomass in units of $\mathrm{N}$ for regions $1-9$ is 17.0, 16.9, $18.8,7.6,13.9,10.1,13.2,43.1$, and $28.6 \%$, respectively. It should be noted the increased role of individual biomass in the transfer of forms of $\mathrm{N}$ : the phytoplankton $F 1 \mathrm{~N}$ in areas the Kandalaksha Bay (7.0\%), the Dvina Bay (18.3\%), the Solovetskie Islands (6.7\%), the Gorlo (5.4\%), and the Chupa Bay (11.8\%); the phytoplankton F3N in the Voronka area (6.1\%); the zooplankton $Z 1 \mathrm{~N}$ - in the Onega Bay (7.4\%), the Basin (4.3\%), the Chupa Bay (7.1\%); the zooplankton Z2N - in the Voronka (11.3\%) and Chupa Bay (8.3\%).

The basic chemical forms of $\mathrm{P}$ (DOP, PD, and DIP) are actively involved in the transport by water masses across the boundaries of regions. However, the relative contribution of these forms in the spatial transport of $\mathrm{P}_{\text {tot }}$, calculated in $\mathrm{g} \mathrm{P} /\left(\mathrm{m}^{3} \times\right.$ year $)$, differs significantly in the sea regions: its share is the largest for DOP (23.6-84.2\% ) (low for the Basin, and high for the Mezen' Bay); for PD - the share in the transfer is $0.2-34.2 \%$ (the lowest for the Gorlo, the largest for the region of the Solovetskie Islands); for DIP, this share ranges from 0 to $24.9 \%$ (there is no transfer of DIP in the Mezen' Bay, and a high proportion is for the Gorlo area).

The role of individual biomass in the transfer of $\mathrm{P}$ forms has been increased: the phytoplankton F1P in the Kandalaksha Bay (22.1\%), the Dvina Bay $(21.2 \%)$, the Solovetsrie Islands (17.5\%), the Gorlo (8.2\%), the Chupa Bay (7.7\%); the zooplankton $Z 1 \mathrm{P}$ - in areas of the Onega Bay (7.8\%), the Basin (16.9\%), the Voronka (18.4\%); the zooplankton $Z 2 \mathrm{P}$ - in the Basin (8.5\%) and the Voronka (12.9\%).

\section{BS input to the White Sea (the Voronka area) at water exchange with the Barents Sea}

River runoff in the White Sea is a significant factor in the formation of a constant water exchange between the White and Barents Seas (Nadezhin, 1966). This water exchange is carried out in the upper layer (40-50 m thick) because of the underwater threshold located at the outlet of the Gorlo. During water exchange, $\sim 2200 \mathrm{~km}^{3}$ of water flows from the White Sea to the Barents Sea annually, and $2000 \mathrm{~km}^{3}$ from the Barents Sea back to the White Sea (Zalogin, Kosarev, 1999). Based on CNPSi-mode calculations, the influence of the water exchange between the seas is assessed as the BS arrival to the White Sea and their removal. The water of the Voronka area distinguishes from other regions of the sea the values of the arrival of certain forms of $\mathrm{N}$ and $\mathrm{P}$ from the Barents Sea: the $\mathrm{N}_{\text {tot }}$ input is $0.0986 \mathrm{~g} \mathrm{~N} /\left(\mathrm{m}^{3} \times\right.$ year) (or 132.8 thousand tons of $\mathrm{N}$ ) (Table 1); the DON and $\mathrm{NO}_{3}$ input in - to 0.0258 , and on the UR is $0.0347 \mathrm{~g} \mathrm{~N} /\left(\mathrm{m}^{3} \times\right.$ year) $(34.8$ and 46.7 thousand tons of $\mathrm{N})$, and the receipt of $\mathrm{P}_{\text {tot }}$ is $0.0253 \mathrm{~g} \mathrm{P} /\left(\mathrm{m}^{3} \times\right.$ year) $(34.1$ thousand tons op P) (Table 2); for DIP, DOP, and PD, respectively, 0.0121, 0.0119 and 0.0014 $\mathrm{g} \mathrm{P} /\left(\mathrm{m}^{3} \times\right.$ year $)$ or $16.3,16.0$ and 1.9 thousand tons of $\mathrm{P}$. 


\section{Input of BS with components of marine pollution}

Under anthropogenic impact, the regions of the White Sea are undergo the various pollution of the marine environment. Several criteria for this impact have been singled out: 1. weak (characteristic for open water areas far from the coast, it is a consequence of the natural transport of dissolved and suspended substances by currents, their supply to the marine environment with atmospheric precipitation); 2. moderate (noted in zones of influence of currents, in frontal areas and in water areas near river mouths - usually in these areas, increased pollution of sea water, uneven changes in space and in time of indicator concentrations of the sea water state are registrated); 3. strong (it is fixed with a sharp increase in marine pollution in offshore areas, river mouths and estuaries, areas of intensive fishing and development of offshore hydrocarbon fields); and 4. greatly strong (it is manifested in areas directly influenced by anthropogenic factors that act separately or together and bring the ecosystem out of the normal mode of operation for different periods of time) (Tolstikov, 2016). However, these criteria do not have enough quantitative values, which will eventually appear.

Anthropogenic impact on the ecosystem of the White Sea associated with the pollution of the marine environment by BS, is a direct result of discharges to the offshore waters of sewage (domestic, agricultural and industrial). It is the pollution of sea water by BS (forms of $\mathrm{N}$ and $\mathrm{P}$ ) that is of greatest interest for this study, since the inevitable consequence in the increasing of BS concentrations in sea waters is the intensification of eutrophication trends in the marine environment.

Discharge of sewage from enterprises of cities and towns in coastal areas and river mouths is a significant source of the pollution of the White Sea waters (Kotova et al., 2016). The state of ecological stress is expressed for the water areas of the Arkhangelsk and Solombala pulp and paper plants, where the sewage is to discharged (Zabelina et al., 2006). However, it is quite difficult to identify any trend in the time of discharge of wastewater from the available information. For example, in the waters of the Karelian and Pomor shores of the White Sea, the discharges of sewage (million $\mathrm{m}^{3}$ ) were: in $2006-83.45 ; 2009$ $-71.75 ; 2011-64.80 ; 2012-73.28 ; 2013-54.47$ (the average is $\sim 70$ million $\mathrm{m}^{3}$ ) (State report ..., 2012, 2013, and 2014). The contamination of suspended solids with wastewater into the marine waters is estimated at 1000 tons, ammonium $\mathrm{N}-202.89$ tons, phosphates 135.65 tons, nitrite -100.91 tons, petroleum products -21.6 tons (Tolstikov, 2016). In the Kandalaksha Bay of the White Sea, discharges of sewage (million $\mathrm{m}^{3}$ ) were: in $2008-10.8$ (without purification 4\%); in 2009 in the mouth of the Onega River, and the Kandalaksha and Dvina bays $-1.133,10.5$ and 254.5 , respectively $(0.7,4.9$ and $6.6 \%$ without purification); in 2010 - in the same water areas - 1.074, 10.8 and 278.7 (without purification -0.7 , 4.0 and 4.8\%); in $2012-1.084,7.135$ and 235.75 (discharges without purification into the Onega and Dvina Bays were decreased respectively to 0 and $0.6 \%$ ). The discharge of wastewater without purification remained high in the the Kandalaksha Bay - in 2011 and 2012 - respectively 44.9 and $27.8 \%$. In total, in 2012, the amount of sewage discharged unto the White Sea was 237-244 million $\mathrm{m}^{3}$ (1.4\% without purification) (Leonov et al., 2017). 
To calculate the effect of wastewater discharges on the content of BS in the waters of different regions of the White Sea, it is necessary to have data not only on the amount of wastewater discharged, but also on the concentrations of the $\mathrm{N}$ and $\mathrm{P}$ forms in wastewater. These data make it possible to estimate the total number of incoming BS in wastewater discharges (or BS loading) per unit of time, and then by dividing the load by the volume of sea waters, it is possible to estimate the total BS flux rate into the marine environment for a specific time.

In the White Sea, zones of anthropogenic impact on the marine waters area have been identified (in particular, on the Kandalaksha Bay - zone of influence of the Kola Peninsula; on the bays Onega, Dvina, and Mezen' - the zone of influence of the NorthWestern catchment area of the White Sea) (Moiseenko, 2010). From the watersheds of the Pomory coast (the river Kem'), pollution of the sea water with ammonium $\mathrm{N}$ is carried out, from the Zimnij coast - with easily oxidizable organic substances (the Mudyuga River), and ammonium nitrogen (the Zolotitsa River); from the Tersky and Kandalaksha coasts - nitrate N (the Sosnovka and the Varzuga Rivers); from the Abramovsky Coast - easily oxidized organic components (the Mezen' River) (Bryzgalo, Ivanov, 2002; Tolstikov, 2016).

According to the terms of nature use, the water areas of the Dvina and Kandalaksha bays are subject to the greatest anthropogenic impact (Kadashova, 2011). On the complex map of anthropogenic impact on the catchment area of the White Sea, taking into account the urbanization of the territory, population density, plowing of land, technogenic impact (Ecological ..., 2002), the pollution areas - Dvina and Onega Bays, and the right (Zimnij) coast of the Gorlo area, as well as the least anthropogenic impact - the waters of the left coast of the Gorlo artea (Tersky shore) and the right coast of the Voronka (Kaninskii shore) (Tolstikov, 2016). A special role in anthropogenic pollution of the coastal waters of the sea belongs to the territories of individual ports (Arkhangelsk, Severodvinsk, Belomorsk, Kem', Kandalaksha, Onega, Mezen', Vitino). For the territories of seaports and adjacent routes of intensive sea transport, the pollution of the marine environment by oil products and petroleum hydrocarbons is typical (Tolstikov, 2016; Leonov et al., 2017).

The input of BS with wastewater is directly related to the development of communal services on the coast. This index is recognized as significant in assessing the ecological status of the waters of the Kandalaksha, Onega, Dvina and Mezen' Bays. For the water areas of these bays, as well as for the Basin, Gorla and Voronka, the input of BS serves as a significant factor in the ecological problem of the formation of seawater productivity (Kadashova, 2011).

Thus, at present, the established fact is the anthropogenic impact on the White Sea and the manifestation of the consequences of this impact on the ecological state of individual marine areas of the sea. The results of a number of generalizations of available anthropogenic impact indicators, the analysis of the location of pollution sources and data on the quality of river waters on the White Sea catchment clearly show that the Dvina Bay - the water area of the maximum impact of incoming pollutants into its waters and with wastewater discharges, and with river runoff. There is also strong anthropogenic impact 
on the waters of the Kandalaksha Bay, the water area of the Pomor and Zimnij Shores of the White Sea (Kadashova, 2011; Tolstikov, 2016).

The content of $\mathrm{N}_{\text {tot }}$ in the domestic wastewater is $50-60 \mathrm{mg} / \mathrm{L}$ (Yagov, 2008). If we focus on this concentration of $\mathrm{N}_{\text {tot }}$ and the values of wastewater discharges in 2012 in the waters of the Kandalaksha and Dvina bays $\left(7135.31 \times 10^{3}\right.$ and $235750.13 \times 10^{3} \mathrm{~m}^{3} /$ year respectively (Leonov et al., 2017)), the design load by $\mathrm{N}_{\text {tot }}$ will be for these water areas accordingly 356.0-428.1 (average 392.0) and 11787-14145 (12966) tons of N/year.

The calculated load of 356.0-428.1 tons of N/year is close to the calculated values of $\mathrm{N}_{\text {tot }}$ input with the runoff of the Niva and Keret' Rivers, whose annual runoff as a whole is insignificant $\left(4.2-0.72 \mathrm{~km}^{3}\right)$. The increased value of the load of 11787-14145 tons $\mathrm{N} /$ year corresponds to the values determined by the flow of the rivers Kem', Onega and Mezen' (Table 1), their annual runoff is $6.7,15.1$ and $20.5 \mathrm{~km}^{3} /$ year, respectively. Here, however, it is not the flow value itself that is important, but the ratio of water runoff to the volume of water in a particular region where the river flows. This ratio varies throughout a year due to fluctuations in river flow. For example, in the Niva River (empties into the Kandalaksha Bay), this ratio is 0.0056 at the spring maximum, and 0.0037 at the smallest flow (February) (difference is only 1.5 times). In other rivers this excess is higher: in the Kem' River (the Solovetskie Islands) - 2.7 times (with fluctuations in the ratio of 0.0032-0.0012), in the Keret' River (the Chupa Bay) - 4.3 times (0.1140-0.0263), and even higher in the Northern Dvina (the Dvina Bay) - 20 times (0.0822-0.0041), Mezen' (the Mezen' Bay) - 20.5 times (0.1207-0.0059) and Onega (the Onega Bay) - 27.5 times (0.0385-0.0014) (Leonov, Chicherina, 2004). With such large fluctuations in the values of ratio between the water flow/volume marine waters during a year, it is clear that the main effect of the water runoff on the content of BS in marine waters is manifested in the spring, when both the river runoff and the BS concentration in it significantly exceed their values in other months.

At the same time, it is important that two factors of BS inputs in a year to the marine areas (with river runoff and effluent discharges) can have the same effect on the marine environment in terms of their influence, intensity and expression of manifestation. It is permissible that, depending on the ratio of water flow/volume of sea water, the anthropogenic impact of these load sources can be either moderate or strong according to definition (Tolstikov, 2016). Thus, the influence of these load sources should be considered as relatively comparable in terms of the annual average values. This means, that at the estimating the BS arrival in the White Sea, one can rely on the values obtained in calculations on the CNPSi-model based on the actual long-term monthly BS concentrations in river waters and rates of the water exchange.

It should be noted that it is not so simple to be guided by the available data on river runoff. The influence of river flow is significantly higher in the spring period (in different rivers for the spring it is $\sim 20-35 \%$ of annual water runoff, and for the removal of BS - up to $45-77 \%$ of their annual removal). In addition, river waters are characterized by different proportions between mineral and organic forms of $\mathrm{N}$ and $\mathrm{P}$, and between the content of these fractions and their total concentrations (Leonov, Chicherina, 2004). 
At the same time, there is a reason to believe that in comparison with the river runoff, the influence of which is significant in the spring period, wastewater discharged to the sea (as an external source of BS) is more significant for the summer period. During this period, their discharge is preferable taking into account the more favorable conditions in the marine environment for the transformation of BS contained in the wastewater.

Thus, in this study, the $\mathrm{N}_{\text {tot }}$ and $\mathrm{P}_{\text {tot }}$-load in the sea area provided by wastewater discharges was estimated indirectly: the BS input rates for the summer period were selected by comparison in a series of numerous calculations with estimated values of BS inputs with river runoff in the spring period. The following $\mathrm{N}_{\text {tot }}$ receipts (in $\mathrm{g} \mathrm{N} /\left(\mathrm{m}^{3} \times\right.$ year), thousand tons of $\mathrm{N}$ ) were estimated for anthropogenic influence of sewage discharges in waters of regions 1-9 of the White Sea respectively: 0.1422, $10.1-0.1545,21.1-0.1593,71.7-0.1545,9.1-0.1473,37.7-0.3280,130.8-0.3280$, $110,9-0.3307,445.4-0.1352,0.2$ (табл. 1$)$, as well as the receipt of $\mathrm{P}_{\text {tot }}\left(\mathrm{g} \mathrm{P} /\left(\mathrm{m}^{3} \times\right.\right.$ year $)$, thousand tons of $\mathrm{P}$ ) to the specified sea regions: $0.0133,1.0-0.0150,2.1-0.0150$, $6.7-0.0127,0.8-0.0187,4.8-0.0020,0.8-0.0086,2.9-0.0055,7.4-0.0187,0.02$ (Table 2). In general, the relative contribution of the annual sewage discharge as a BS load source is comparable to the load provided by river runoff in regions 1-5 and 9 of the White Sea, where the rivers (Niva, Onega, Severnaya Dvina, Mezen', Kem' and Keret' respectively) flow to the sea regions. It should be noted that in general, river flow accounts for $0.5-7.5 \%$ and $0.3-10.4 \%$ of total annual inputs of $\mathrm{N}_{\text {tot }}$ and $\mathrm{P}_{\text {tot }}$ respectively from all other sources. The load determined by wastewater discharges accounts for 3.0-6.6\% and $0.6-1.9 \%$ of the total annual supply of $\mathrm{N}_{\text {tot }}$ and $\mathrm{P}_{\text {tot }}$ respectively, that is comparable to the load formed by river runoff. Some distinctions may be considered as unimportant due to generally low contributions of these sources to the estimated total BS load on the marine areas (Tables 1, and 2).

\section{Amount of DON and DOP formed at the decay of detritus (ND and PD)}

The detritus present in the water environment and formed during the biomass death are the component that participate in the continuous cycling of BS in the water environment. One of the ways of this cycle is the decomposition of detritus (ND and PD), depending on the temperature of the water environment, to the dissolved components containing $\mathrm{N}$ (DON) and $\mathrm{P}$ (DOP). These internal fluxes of BS were the subject of research: for all areas of the White Sea, their numbers in the implementation of the CNPSi-model were calculated at each time steps, and by adding them - for each month and then for a year.

The amount of DON formed in the decomposition of ND (in $\mathrm{g} \mathrm{N} /\left(\mathrm{m}^{3} \times\right.$ year) and thousand tons of $\mathrm{N}$ ) in the White Sea regions can be represented by the following sequence: the Gorlo $(0.2914,98.6)$ - the Basin $(0.3723,148.5)$ - the Voronka $(0.4219,568.3)$ the Chupa Bay $(0.4850,0.6)$ - the Onega Bay $(0.5284,72.1)$ - the Solovetskie Islands $(0.5314,135.9)$ - the Mezen' Bay $(0.5379,31.7)$ - the Kandalaksha Bay $(0.7318,52.1)-$ the Dvina Bay $(1.4271,642.2)$ (Table 1$)$. A similar series for the DOP $\left(\mathrm{g} \mathrm{P} /\left(\mathrm{m}^{3} \times\right.\right.$ year $)$ and thousand tons of $\mathrm{P}$ ) formed during a year is characterized by the following sequence of 
regions: the Gorlo $(0.0692,23.4)$ - the Voronka $(0.0886,119.3)$ - the Chupa Bay $(0.1010$, $0.1)$ - the Mezen' Bay $(0.1538,9.1)$ - the Basin $(0.1660,66.2)$ - the Onega Bay $(0.1956$, $26.7)$ - the Solovetskie Islands $(0.2028,51.9)$ - the Kandalaksha Bay $(0.2881,20.5)$ the Dvina Bay $(0.5012,225.5)$ (Table 2).

There are some differences in the sequence of regions in the middle part of these series, characterizing in $\mathrm{E}$ Element $/\left(\mathrm{m}^{3} \times\right.$ year $)$ the estimated amounts of organic components (DON and DOP) formed during a year in the detritus decay. However, the flanks in the constructed rows occupy the same regions: on the left - the Gorlo region, and on the right - the Kandalaksha and Dvina bays. This indicates that there are some differences in the sea regions in the BS transformations and inputs, but there are no principal trends that could significantly affect the intra-annual BS transformations and the changes in the most important internal fluxes of replenishment of BS over the sea regions: and according to $\mathrm{N}$, and according to $\mathrm{P}$, the picture of the formation of the smallest and largest internal resources of BS among the sea regions is virtually the same.

\section{OUTPUT CONSTITUENTS IN BALANCES OF N AND P}

The formation of the components in the expenditure parts of the $\mathrm{N}$ and $\mathrm{P}$ balances determine the internal processes that develop in the water environment, and in particular:

- BS consumption by the community of organisms - the heterotrophic bacteria $B 1$, three groups of phytoplankton $(F 1, F 2$ and $F 3)$, two groups of zooplankton $(Z 1, Z 2)$ and macrophytes $(M K)$;

- the sedimentations of particulate BS forms (ND and PD);

- the removals of BS and biomass of organisms during the water exchange between neighboring regions of the White Sea;

- the BS removal from the White Sea to the Barents Sea during the water exchange (across the boundary of the Voronka area - the Barents Sea) (Tables 1, and 2).

\section{Total consumption of BS by the community of organisms}

The main costs of BS are provided by the total impact of the community of organisms using BS for biomass construction during the active period of its development. The following series shows the values of the total annual consumption of $\mathrm{N}_{\text {tot }}$ (in $\mathrm{g} \mathrm{N} /\left(\mathrm{m}^{3} \times\right.$ year) and in thousand tons of $\mathrm{N}$ ) by the community of organisms (the bacteria $B 1$, the phytoplankton $F 1-F 3$, the zooplankton $Z 1-Z 2$, macrophytes $M K$ ) in the sea regions: the Dvina Bay $(3.4307,1543.8)$ - the Chupa Bay $(2.0860,2.4)$ the Mezen' Bay $(1.8684,110.2)$ - the Kandalaksha Bay $(1.7799,126.7)$ - the Solovetskie Islands $(1.7687,452.4)$ - the Onega Bay $(1.7530,239.3)$ - the Gorlo $(1.2783,432.3)$ the Voronka $(1.2385,1668.3)$ - the Basin $(0.5025,200.0)$ (Table 1).

Sequence of sea areas according to annual consumption by the community of organisms $\mathrm{P}_{\text {tot }}$ (in $\mathrm{g} \mathrm{P} /\left(\mathrm{m}^{3} \times\right.$ year) and thousand tons of $\mathrm{P}$ ) is represented by the following series: the Dvina Bay $(1.7048,767.2)$ - the Kandalaksha Bay $(0.8690,61.9)$ - 
the Solovetskie Islands $(0.8595,219.9)$ - the Onega Bay $(0.8227,112.3)$ - the Mezen' Bay $(0.8179,48.3)$ - the Chupa Bay $(0.8147,0.9)$ - the Gorlo $(0.5529,187.0)$ the Voronka $(0.4848,653.0)$ - the Basin $(0.3714,147.8)$ (Table 2).

Note that in these two series (for $\mathrm{N}$ and $\mathrm{P}$ ), the same regions are located on the flanks in terms of the consumed amounts of $\mathrm{N}$ and $\mathrm{P}$ (in $\mathrm{g}$ Element $/\left(\mathrm{m}^{3} \times\right.$ year $)$ ) - on the left with maximal consumption (of $\mathrm{N}$ or $\mathrm{P}$ ), and in the right - with minimal consumption (of $\mathrm{N}$ or $\mathrm{P})$. In the central part of the series, the region transpositions are possible, indicating changes in the biomass development in these regions due to differences in the conditions of input and transformation of BS. Thus, regions on the flanks presumably characterize extreme conditions for the development of biomass of organisms. On the basis of a system analysis of the conditions in the dynamics of the $\mathrm{N}$ and $\mathrm{P}$ forms, the same regions are identified - the Dvina Bay on the left flank (with the most favorable conditions and active development of biomass) and three regions (the Gorlo, the Voronka, and the Basin) on the right flank (with the least favorable conditions for the development of biomass). On the basis of a more detailed analysis of the internal $\mathrm{N}$ and $\mathrm{P}$ fluxe values, the differences in the features of the biomass development of individual groups of organisms and, in particular, in their consumption of various forms of $\mathrm{N}$ and $\mathrm{P}$ can be determined for the sea regions.

\section{BS consumption by the heterotrophic bacteria $B 1$}

According to the regions of the White Sea, the relative losses of $\mathrm{N}$ and $\mathrm{P}$ for consumption by the bacteria $B 1$ are respectively $2.2-16.4 \%$ and $1.7-8.0 \%$ (the largest in the Basin, and the least in the Onega Bay (for N) and in the Gorlo (for P). In the regions of the White Sea, the annual consumption of $\mathrm{N}_{\text {tot }}$ by the bacteria $B 1$ are in range $0.0500-0.2744 \mathrm{~g} \mathrm{~N} /\left(\mathrm{m}^{3} \times\right.$ year) (Table 1$)$. The bacterial composition of $\mathrm{N}$ forms includes DON and ND. The amount DON consumed by the bacteria $B 1$ is $0.0189-0.1762$, and $\mathrm{ND}$ is $0.0099-0.1159 \mathrm{~g} \mathrm{~N} /\left(\mathrm{m}^{3} \times\right.$ year$)$. The smallest bacterial consumption of all $\mathrm{N}$ forms was noted in the Onega Bay, and the largest consumption was recorded in the Chupa Bay (for of $\mathrm{N}_{\text {tot }}$, and DON) and in the Voronka area (for ND).

The consumption of $\mathrm{P}_{\text {tot }}$ by the bacteria $B 1$ varies over the sea regions in the range of $0.0104-0.0593 \mathrm{~g} \mathrm{P} /\left(\mathrm{m}^{3} \times\right.$ year) (Table 2$)$. In the sea regions, the concentration ranges of DOP and PD consumed during a year by the bacteria $B 1$ varies respectively within $0.0009-0.0297$ and $0.0087-0.0310 \mathrm{~g} \mathrm{P} /\left(\mathrm{m}^{3} \times\right.$ year $)$. The lowest consumption of $\mathrm{P}$ components was observed in the Gorlo area, and the largest - in the Dvina Bay. Also increased consumption of DOP is in the Solovetskie Islands region, and PD - in the waters of the Chupa Bay.

In general, the different sequence of the White Sea regions according to the varied amount of $\mathrm{N}$ and $\mathrm{P}$ compounds consumed by the bacteria $B 1$ is noted. This is evidence of the changeable conditions for the development of bacteria $B 1$ biomasses - in the input of $\mathrm{N}$ and $\mathrm{P}$ forms from external sources, as well as significant differences in the internal recycling of $\mathrm{N}-$ and $\mathrm{P}-$ containing $\mathrm{BS}$ in the marine waters in sea areas. 


\section{BS consumption by the phytoplankton $F 1$}

In the regions of the White Sea, the relative losses of $\mathrm{N}$ and $\mathrm{P}$ on the phytoplankton $F 1$ consumption vary respectively within $5.6-42.6 \%$ and $4.8-38.1 \%$ (the largest values are in the Basin, and the smallest ones - in the Onega Bay). The consumption of $\mathrm{N}_{\text {tot }}$ by the phytoplankton $F 1$ varies in the various regions in the range $0.1251-0.5097 \mathrm{~g} \mathrm{~N} /\left(\mathrm{m}^{3} \times\right.$ year $)$ (Table 1). $\mathrm{NO}_{3}, \mathrm{UR}$ and $\mathrm{NH}_{4}$ - are the most preferable $\mathrm{N}$ forms for the phytoplankton $F 1$. In the regions of the White Sea, the amounts of $\mathrm{NO}_{3}, \mathrm{UR}$ and $\mathrm{NH}_{4}$ consumed for a year by the phytoplankton $F 1$ vary respectively in ranges $0.0750-0.2231,0.0304-0.1434$, and $0.0186-0.1816 \mathrm{~g} \mathrm{~N} /\left(\mathrm{m}^{3} \times\right.$ year $)$. The region with the lowest uptake of $\mathrm{N}$ forms by the phytoplankton $F 1$ - the Onega Bay, and the regions with the largest consumption are the Chupa Bay $\left(\mathrm{N}_{\text {tot }}, \mathrm{NO}_{3}\right.$ and $\left.\mathrm{NH}_{4}\right)$ and the Dvina Bay (UR).

Annual consumption of $\mathrm{P}_{\text {tot }}$ by the phytoplankton $F 1$ fluctuates in the regions of the White Sea in the range $0.0470-0.1668 \mathrm{~g} \mathrm{P} /\left(\mathrm{m}^{3} \times\right.$ year) (Table 2$)$. For the phytoplankton $F 1$, the dissolved forms of $\mathrm{P}$ (DIP and DOP) serve as the $\mathrm{P}$ substrates. In the regions of the White Sea, the amounts of DIP and DOP consumed by the phytoplankton $F 1$ per a year DIP and DOP varies respectively within 0.0166-0.0501 and 0.0251-0.1167 $\mathrm{g} \mathrm{P} /\left(\mathrm{m}^{3} \times\right.$ year $)$. Regions with the lowest consumption of $\mathrm{P}$ forms by the phytoplankton $F 1$ are the Onega Bay $\left(\mathrm{P}_{\text {tot }}\right.$, DOP) and the Gorlo (DIP), and the greatest consumption was noted in the Basin area.

The analysis of the activity of BS consumption by the phytoplankton $F 1$ in the regions of the White Sea was shown that the consumption of mineral forms of $\mathrm{N}$ and $\mathrm{P}$ is the least active in the Onega Bay, and their greatest activity is changing: for $\mathrm{N}$ forms, it occurs on the Chupa Bay and the Dvina Bay and for the P forms - in the Basin area.

\section{BS consumption by the phytoplankton $F 2$ and $F 3$}

The annual BS consumption by the phytoplankton, not related to the diatom phytoplankton $F 1$, is the least in comparison with the consumption by other organisms. This is confirmed by the direct hydrobiological observations showing the low activity of different groups of phytoplankton in the transformations of BS and organic matter (OM) in comparison with the diatom phytoplankton $F 1$ (Ilyash et al., 2003). For the regions of the White Sea, the changes in the relative losses of $\mathrm{N}$ and $\mathrm{P}$, estimated on the consumption by the phytoplankton $F 2$, are $0.2-2.3 \%$ and $0.1-1.3 \%$ respectively, and for $F 3-0.2-2.7 \%$ and $0.1-1.3 \%$ (the lowest values are in the Basin, and the largest one - in the Onega Bay). Calculations showed that the mass of $\mathrm{N}_{\text {tot }}$ and $\mathrm{P}_{\text {tot }}$, consumed during a year by the phytoplankton $F 2$, varies in the regions of the White Sea in the ranges 0.0012-0.0511 $\mathrm{g} \mathrm{N} /\left(\mathrm{m}^{3} \times\right.$ year) and $0.0003-0.0131 \mathrm{~g} \mathrm{P} /\left(\mathrm{m}^{3} \times\right.$ year) (Table 1 , and 2$)$. The consumption of $\mathrm{N}$ forms by the phytoplankton $F 2$ varies considerably in the regions of the White Sea: $\mathrm{NH}_{4}$ accounts for $8.4-27.3 \%$ (the lowest in the Kandalaksha Bay, and the largest - in the Chupa Bay), $\mathrm{NO}_{3}-7.6-33.5 \%$ (the lowest in the Gorlo area, and the largest - in the waters of the Solovetskie Islands), and UR - 53.8-78.4\% (the smallest is in the Chupa Bay, and 
the largest - in the Gorlo and Voronka areas). In the regions of the White Sea, the proportions of the P forms (DIP and DOP) uptaken by the phytoplankton $F 2$ are also changed: for DIP $-24.1-30.9 \%$ and for DOP $-69.1-75.9 \%$.

In the regions of the White Sea, estimates of the activity of the annual consumption of $\mathrm{N}_{\text {tot }}$ and $\mathrm{P}_{\text {tot }}$ by the phytoplankton $F 3$ fluctuate respectively in the ranges $0.0014-0.0615$ $\mathrm{g} \mathrm{N} /\left(\mathrm{m}^{3} \times\right.$ year) and $0.0002-0.0121 \mathrm{~g} \mathrm{P} /\left(\mathrm{m}^{3} \times\right.$ year) (Table 1 , and 2$)$. The proportions of $\mathrm{N}$ forms consumed by the phytoplankton $F 3$ are: $\mathrm{NH}_{4}-9.9-31.3 \%$ (the lowest is in the Kandalaksha Bay, and the largest is in the Chupa Bay), $\mathrm{NO}_{3}$ is $5.3-42.0 \%$ (the lowest is in the Gorlo area, and the largest is in the Onega Bay), UR - 44.7-86.7\% (the lowest in the Onega Bay, and the largest - in the Dvina Bay). The share of DIP uptaken by the phytoplankton $F 3$ varies in the sea regions within $14.4-35.5 \%$, and DOP $-64.5-85.6 \%$.

Thus, the amount of combined consumption of $\mathrm{N}_{\text {tot }}$ and $\mathrm{P}_{\text {tot }}$ by the phytoplankton $F 2$ and $F 3$ was lower than the consumption by the diatom phytoplankton $F 1$ by $4-83$ and 7-94 times respectively.

\section{BS consumption by the herbivorous zooplankton $Z 1$}

In the regions of the White Sea, the relative loss of $\mathrm{N}$ on the consumption by the herbivorous zooplankton $Z 1$ is estimated in the range $12.5-23.9 \%$ (it is the lowest in the Mezen' Bay, and the largest - in the Gorlo area). The annual consumption of $\mathrm{N}_{\text {tot }}$ by the zooplankton $Z 1 \mathrm{~N}$ ( $\mathrm{g} \mathrm{N} /\left(\mathrm{m}^{3} \times\right.$ year) and in thousand tons of $\left.\mathrm{N}\right)$ decreases in the regions of the White Sea in the following order: the Dvina Bay $(0.7105,319.7)$ - the Solovetskie Islands $(0.4584,117.3)$ - the Chupa Bay $(0.4544,0.5)$ - the Gorlo $(0.4435,150.0)$ the Onega Bay $(0.4011,54.8)$ - the Kandalaksha Bay $(0.3726,26.5)$ - the Mezen' Bay $(0.3260,19.2)$ - the Voronka $(0.2419,325.8)$ - the Basin $(0.0856,34.1)$ (Table 1).

Detritus ND is the most important $\mathrm{N}$ substance consumed by the zooplankton $Z 1$ : the proportion of its consumption, calculated per unit of the water volume, in the regions of the Kandalaksha Bay, the Onega Bay, the Dvina Bay, the Solovetskie Islands, and the Gorlo area is $91.3-94.6 \%$, in the Mezen' Bay, the Chupa Bay, and the Voronka area $-84.8-88.6 \%$, and in the Basin $-46.1 \%$. The consumption of the phytoplankton $F 1$ biomass by the zooplankton $Z 1$ is increased: in the Basin area (43.3\%), the Mezen' Bay (11.4\%), and the Chupa Bay (9.2\%).

In the regions of the White Sea, the amount of ND, biomasses $B 1, F 1, F 2$, and $F 3$, consumed for a year by the zooplankton $Z 1$ varied respectively in the ranges $0.0395-0.6508$, $0.0054-0.0451,0.0188-0.0451,0.0001-0.0010$, and $0.0001-0.0008 \mathrm{~g} \mathrm{~N} /\left(\mathrm{m}^{3} \times\right.$ year $)$. The smallest amount of $\mathrm{N}$ compounds is consumed in the Basin area $\left(\mathrm{N}_{\text {tot }}, B 1 \mathrm{~N}\right)$, the Gorlo area $(F 1 \mathrm{~N})$, and the Voronka area $(F 2 \mathrm{~N}$, and $F 3 \mathrm{~N})$, and the largest amount - in the Dvina Bay $\left(\mathrm{N}_{\text {tot }}, \mathrm{ND}, F 1 \mathrm{~N}\right)$, and the Onega Bay $(F 2 \mathrm{~N}$, and $F 3 \mathrm{~N})$.

In the regions of the White Sea, the consumed amount of $\mathrm{P}_{\text {tot }}$ by the zooplankton Z1P (in $\mathrm{g} \mathrm{P} /\left(\mathrm{m}^{3} \times\right.$ year) and in thousand tons of $\mathrm{P}$ ) can be traced along in the following series: the Dvina Bay $(0.3916,176.2)$ - the Chupa Bay $(0.2328,0.3)$ - the Solovetskie Islands $(0.2119,54.2)$ - the Gorlo area $(0.1972,66.7)$ - the Onega Bay $(0.1747,23.9)-$ 
the Kandalaksha Bay $(0.1712,12.2)$ - the Mezen' Bay $(0.1576,9.3)$ - the Voronka area $(0.1473,198.4)$ - the Basin area $(0.0935,37.2)$. The relative losses $\mathrm{P}$ uptaken by the zooplankton $Z 1$ vary in the regions of the White Sea in the range of $15.7-35.0 \%$ (Table 2).

The largest amount of $\mathrm{P}$, the zooplankton $Z 1$ derives from the consumption of PD: its share in the total mass of the consumed $\mathrm{P}$, calculated per the unit of water volume, is $71.3 \%$ in the Basin area, and $90.8-94.9 \%$ in the remaining regions of the White Sea. The share of consumed other P substances varies in the range $0.1-6.4 \%$ in the regions of the White Sea.

The total amount of $\mathrm{P}$ compounds (PD, and biomasses B1P, F1P, F2P, and F3P) uptaken by the zooplankton $Z 1 \mathrm{~N}$ fluctuates respectively in the range $0.0667-0.3665$, $0.0027-0.0112,0.0055-0.0207,0.0001-0.0007$, and $0.0001-0.0005 \mathrm{~g} \mathrm{P} /\left(\mathrm{m}^{3} \times\right.$ year $)$ in the regions of the White Sea.

The smallest amount of the $\mathrm{P}$ substances, the zooplankton $\mathrm{Z1N}$ consumes in the Basin area $\left(\mathrm{P}_{\text {tot }}, \mathrm{PD}, F 2 \mathrm{P}, F 3 \mathrm{P}\right)$, the Gorlo area $(B 1 \mathrm{P})$, and the Onega Bay $(F 1 \mathrm{P})$, and the largest amount - in the Dvina Bay $\left(\mathrm{P}_{\text {tot }}, \mathrm{PD}\right.$, and $\left.B 1 \mathrm{P}\right)$, the Basin area $(F 1 \mathrm{P})$, the Chupa Bay (F2P), and the Mezen' Bay (F3P).

\section{BS consumption by the predatory zooplankton $Z 2$}

According to the annual consumption of $\mathrm{N}_{\text {tot }}$ by the predatory zooplankton $\mathrm{Z} 2$ (in $\mathrm{g} \mathrm{N} /\left(\mathrm{m}^{3} \times\right.$ year) and in thousand tons of $\mathrm{N}$ ), the White Sea regions form the following series: the Dvina Bay $(0.3385,152.3)$ - the Solovetskie Islands $(0.2061,52.7)$ - the Chupa Bay $(0.1605,0.2)$ - the Onega Bay $(0.1588,21.7)$ - the Mezen' Bay $(0.1527$, $9.0)$ - the Gorlo area $(0.1263,42.7)$ - the Kandalaksha Bay $(0.1246,8.9)$ - the Voronka area $(0.0992,120.2)$ - the Basin area $(0.0665,26.5)$ (Table 1). In quantitative terms, the relative $\mathrm{N}$ losses for $\mathrm{N}$ consumption by the zooplankton $Z 2$ are small $(4.5-11.3 \%)$ per unit of the water volume in the regions of the White Sea.

Detritus ND is the main N substance consumed by the zooplankton Z2: its share in the consumption of $\mathrm{N}$ is $54.5-90.1 \%$ per unit of water volume in different sea regions. In some areas, the share of the «living biomass» of $\mathrm{N}$ compounds uptaken by the zooplankton $\mathrm{Z} 2$ are increased: for the phytoplankton $F 1 \mathrm{~N}$ (up to $10.5 \%$ in the Chupa Bay, $10.8 \%$ in the Kandalaksha Bay, $12.6 \%$ in the Mezen' Bay, and $18.8 \%$ in the Basin area), as well as for the zooplankton $Z 1 \mathrm{~N}$ (up to $10.1 \%$ in the Kandalaksha Bay, $10.2 \%$ in the Onega Bay, and $18.9 \%$ in the Basin area). The consumption share of other $\mathrm{N}$ compounds varies within the range of $0.2-9.2 \%$.

The amount of ND consumed per a year is higher than that of «living biomasses» $(B 1 \mathrm{~N}, F 1 \mathrm{~N}, F 2 \mathrm{~N}, F 3 \mathrm{~N}$ and $Z 1 \mathrm{~N})$, and ranges from 0.0362 to $0.2771 \mathrm{~g} \mathrm{~N} /\left(\mathrm{m}^{3} \times\right.$ year) in sea regions (the largest is in Dvina Bay and the smallest - in the Basin area). The amount of «living biomasses» consumed by the zooplankton $Z 2$ in the sea regions varies within the following values: $B 1 \mathrm{~N}-0.0017-0.0109 ; F 1 \mathrm{~N}-0.0050-0.0275 ; F 2 \mathrm{~N}-0.0001-0.0015$; $F 3 \mathrm{~N}-0.0001-0.0020 ; Z 1 \mathrm{~N}-0.0027-0.0219 \mathrm{~g} \mathrm{~N} /\left(\mathrm{m}^{3} \times\right.$ year $)$. The smallest amount of $\mathrm{N}$ compounds is consumed by the zooplankton $\mathrm{Z} 2$ in the Basin area $\left(\mathrm{N}_{\text {tot }}\right.$, and ND), the 
Onega Bay $(B 1 \mathrm{~N})$, the Gorlo area $(F 1 \mathrm{~N})$, the Voronka area $(F 2 \mathrm{~N}, F 3 \mathrm{~N}$, and $Z 1 \mathrm{~N})$, and the largest amount - in the Dvina Bay $\left(\mathrm{N}_{\text {tot }}, \mathrm{ND}, B 1 \mathrm{~N}, F 1 \mathrm{~N}\right.$, and $\left.Z 1 \mathrm{~N}\right)$, and the Onega Bay $(F 2 \mathrm{~N}$, and $F 3 \mathrm{~N})$ (Table 1$)$.

The consumed amount of $\mathrm{P}_{\text {tot }}$ by the zooplankton $22 \mathrm{P}$ (in $\mathrm{g} \mathrm{P} /\left(\mathrm{m}^{3} \times\right.$ year) and in thousand tons of $\mathrm{P}$ ) is characterized by the following values for the sea regions: the Dvina Bay $(0.2636,118.6)$ - the Solovetskie Islands $(0.1406,36,0)$ - the Onega Bay $(0.1151$, $15.7)$ - the Chupa Bay $(0.1144,0.1)$ - the Mezen' Bay $(0.1079,6.4)$ - the Kandalaksha Bay $(0.1033,7.4)$ - the Gorlo area $(0.0821,27.8)$ - the Basin area $(0.0754,30.0)$ - the Voronka area $(0.0686,92.4)$ (Table 2 ). The relative losses of $\mathrm{P}$ to the zooplankton $Z 2$ consumption, calculated per unit of the water volume, are $10.8-17.2 \%$ for the regions of the White Sea.

The zooplankton $Z 2$ obtained a significant amount of $\mathrm{P}$ as a result of the $\mathrm{PD}$ consumption: its share in the $\mathrm{P}$ consumption varies in the sea regions in the range of $75.3-91.8 \%$. The consumption of «living biomass» by the zooplankton $Z 2$ is increased: the phytoplankton $F 1$ - up to $13.1 \%$ in the Basin area, as well as the zooplankton $Z 1$ - up to $11.2 \%$ in the Basin area, up to $10.9 \%$ in the Gorlo area, and up to $10.7 \%$ in the Voronka area). The share of the uptake of other $\mathrm{P}$ compounds is $0.1-9.7 \%$.

The amount of the $\mathrm{P}$ compounds (PD) and «living biomasses» of organisms, consumed by the zooplankton $Z 2$, are significantly different in the sea regions. The total range of consumed $\mathrm{P}$ forms (in $\mathrm{g} \mathrm{P} /\left(\mathrm{m}^{3} \times\right.$ year $)$ ) for the sea areas are: $\mathrm{PD}-0.0568-0.2419$, $B 1 \mathrm{P}-0.00001-0.0002$; F1P-0.0004-0.0.0099; F2P - 0.00001-0.0007; F3P - 0.00001$0.0007 ; Z 1 \mathrm{P}-0.0066-0.0162$. The smallest uptake of the $\mathrm{P}$ forms by the zooplankton $Z 2$ are in areas - the Voronka $\left(\mathrm{P}_{\text {tot }}, B 1 \mathrm{P}, F 1 \mathrm{P}\right.$, and F3P), the Basin $(\mathrm{PD}, F 2 \mathrm{~N})$, the Onega Bay $(Z 1 \mathrm{P})$, and the largest ones - in the Dvina Bay $\left(\mathrm{P}_{\text {tot }}, \mathrm{PD}, B 1 \mathrm{P}, F 1 \mathrm{P}\right.$, and Z1P), the Chupa Bay $(F 2 \mathrm{R}$, and F3P), and the Onega Bay $(F 3 \mathrm{P})$.

\section{BS consumption by macrophytes $M K$}

The annual consumption of $\mathrm{N}_{\text {tot }}$ and $\mathrm{P}_{\text {tot }}$ by macrophytes $M K$ were calculated for all regions of the White Sea except for the deep-water Basin. In the regions of the White Sea, the total ranges in the annual consumption of $\mathrm{N}_{\text {tot }}$ and $\mathrm{P}_{\text {tot }}$ are respectively $0.3568-1.6876$ $\mathrm{g} \mathrm{N} /\left(\mathrm{m}^{3} \times\right.$ year $)$ and $0.1687-0.8653 \mathrm{~g} \mathrm{P} /\left(\mathrm{m}^{3} \times\right.$ year $)$. The smallest quantities of consumed $\mathrm{N}_{\text {tot }}$ and $\mathrm{P}_{\text {tot }}$ are noted in the Voronka area, and the largest - in the Dvina Bay (Table 1, 2). Thus, the relative losses of $\mathrm{N}_{\text {tot }}$ and $\mathrm{P}_{\text {tot }}$ for the consumption by macrophytes $M K$ are the largest in the regions of the White Sea, they vary between $20.4-44.3 \%$ in N and 30.4 $48.8 \%$ in $\mathrm{P}$ (the smallest - in the Voronka area, and the largest - in the Kandalaksha Bay).

The components of the water environment ( $\mathrm{DON}, \mathrm{NH}_{4}, \mathrm{NO}_{2}$, and $\mathrm{NO}_{3}$ ) as well as the mineral $\mathrm{N}$ forms from the bottom sediments $\left(\mathrm{NH}_{4} \mathrm{~s}\right.$, and $\left.\mathrm{NO}_{3} \mathrm{~s}\right)$ are consumed by macrophytes $M K$. The total amount of DON, consumed during a year by macrophytes $M K$, in the sea regions varies within $0.2978-1.5980 \mathrm{~g} \mathrm{~N} / \mathrm{m}^{3}$, the ranges of other $\mathrm{N}$ compounds are: $\mathrm{NH}_{4}-$ from $<0.0001$ to $0.0040, \mathrm{NO}_{2}-$ from $<0.0001$ to 0.0008 , $\mathrm{NO}_{3}$ - from $<0.0001$ to $0.0452, \mathrm{NH}_{4} \mathrm{~s}-$ from 0.0059 to 0.0288 , and $\mathrm{NO}_{3} \mathrm{~s}-$ from 0.0407 
to $0.0739 \mathrm{~g} \mathrm{~N} /\left(\mathrm{m}^{3} \times\right.$ year $)$. The smallest consumption of $\mathrm{DON}$ and $\mathrm{NH}_{4} \mathrm{~s}$ by macrophytes $M K$ were observed in the Voronka area; $\mathrm{NH}_{4}, \mathrm{NO}_{2}$, and $\mathrm{NO}_{3}$ - in the Gorlo area, and $\mathrm{NO}_{3} \mathrm{~s}$ - in the Chupa Bay. The greatest consumption of DON by macrophytes $M K$ is recorded in the Dvina Bay, and $\mathrm{NH}_{4}, \mathrm{NO}_{2}, \mathrm{NO}_{3}$, and $\mathrm{NO}_{3} \mathrm{~s}$ - in the Onega Bay; and $\mathrm{NH}_{4} \mathrm{~s}-$ in the Mezen' Bay.

The $\mathrm{P}$ components for macrophytes $M K$ are the dissolved in water forms (DOP, and DIP) and DIP in bottom sediments (DIPs). In the sea regions, the ranges of the P compounds, uptaken by macrophytes MK during a year vary: for DOP $-0.1087-0.6782$, for DIP 0.0226-0.0891, and for DIPs - 0.0374-0.1042 g P/( $\mathrm{m}^{3} \times$ year $)$. The lowest consumption of $\mathrm{P}$ components was noted in the Voronka area, and the largest - in the Dvina Bay. The consumption of DIPs in the Onega Bay and the Mezen' Bay are also increased.

\section{Sedimentation of ND and PD}

The amount of detritus, annually deposited from the aquatic environment to the bottom, varies quite significantly in the sea regions. The $\mathrm{N}$ losses (as ND) to the sediments (in $\mathrm{g} \mathrm{N} /\left(\mathrm{m}^{3} \times\right.$ year) and in thousand tons of $\left.\mathrm{N}\right)$ of different sea regions are presented in the following row: the Chupa Bay $(0.7708,0.9)$ - the Mezen' Bay $(0.7024,41.4)$ - the Onega Bay $(0.4822,65.8)$ - the Dvina Bay $(0.4420,198.9)$ - the Gorlo area $(0.4326,146.3)$ - the Voronka area $(0.4183,563.4)$ - the Solovetskie Islands $(0.3234,82.7)$ - the Kandalaksha Bay $(0.3025,21.5)$ - the Basin $(0.0375,14.9)$ (Table 1).

The similar line for the values of PD losses on the sedimentation (in $\mathrm{g} \mathrm{P} /\left(\mathrm{m}^{3} \times\right.$ year) and in thousand tons of P) give the next position of sea regions: the Mezen' Bay $(0.1673$, $9.9)$ - the Onega Bay $(0.1461,19.9)$ - the Chupa Bay $(0.1243,0.1)$ - the Dvina Bay $(0.1131,50.9)$ - the Solovetskir Islands $(0.0928,23.7)$ - the Kandalaksha Bay $(0.0838$, $6.0)$ - the Voronka area $(0.0511,68.8)$ - the Basin area $(0.0248,9.9)$ - the Gorlo area $(0.0015,0.5)$ (Table 2). There is a small rearrangement of the same sea regions on the left flank in these rows, where the losses of $\mathrm{N}$ and $\mathrm{P}$ to detritus sedimentation are greatest.

The relative losses $\mathrm{N}$ for detrirus ND sedimentation, calculated per unit of the water volume, over the sea areas $1-9$ are $14.2 \%, 21.4,11.0,26.9,15.1,6.3,23.3,23.9$, and $26.1 \%$ of the total losses $\mathrm{N}$, respectively, and the relative losses of $\mathrm{P}$ by the PD sedimentation in these areas is lower - respectively, 8.7\%, 15.0, 6.2, 16.7, 9.6, 5.6, 0.3, 9.2, and $13.2 \%$ of the total losses of $\mathrm{P}$. The losses of $\mathrm{N}$ and $\mathrm{P}$ for detrital sedimentation are the least, respectively, in the Basin and Gorlo areas, and the largest in the waters of the Chupa Bay and the Mezen' Bay.

Thus, the largest amount of ND per year settles in the Chupa Bay, and in relative units, the ND loss is higher in the Mezen' Bay. Also in the Mezen' Bay, the greatest losses of PD are recorded. The smallest losses of ND (together with the relative losses) are fixed for the Basin area, and the lowest losses of PD are typical for the Gorlo area. 


\section{Output of $\mathbf{N}$ and $P$ to neighboring regions at the water exchange through the region boundaries}

In quantitative terms, the relative losses of $\mathrm{N}$ and $\mathrm{P}$ during the water exchange across the boundaries of areas in comparison with other processes are small: according to $\mathrm{N}_{\text {tot }}$ and $\mathrm{P}_{\text {tot }}$, they fluctuate in the ranges of $0.6-8.5 \%$ and $0.1-9.6 \%$ (the least relative contribution is fixed for the Onega Bay (according to $\mathrm{N}_{\text {tot }}$ ) and for the Chupa Bay (according to $\left.\mathrm{P}_{\text {tot }}\right)$, and the largest for the Basin $\left(\mathrm{N}_{\text {tot }}\right.$ and $\left.\mathrm{P}_{\text {tot }}\right)$.

The following row shows the $\mathrm{N}_{\text {tot }}$ losses in the regions of the White Sea during the water exchange (in $\mathrm{g} \mathrm{N} /\left(\mathrm{m}^{3} \times\right.$ year), thousand tons of $\left.\mathrm{N}\right)$ : the Gorlo area $(0.1445,48.9)-$ the Dvina Bay $(0.1371,61.7)$ - the Chupa Bay $(0.0939,0.1)$ - the Solovetskie Islands $(0.0573,14.7)$ - the Kandalaksha Bay $(0.0537,3.8)$ - the Basin area $(0.0499,19.9)$ - the Mezen' Bay $(0.0378,2.2)$ - the Voronka area $(0.0296,39.9)$ - the Onega Bay $(0.0146$, 2.0) (Table 1).

The location in a line of regions with the $\mathrm{P}_{\text {tot }}$ losses during the water exchange ( $\mathrm{g} \mathrm{P} /\left(\mathrm{m}^{3} \times\right.$ year $)$, thousand tons of $\left.\mathrm{P}\right)$ looks somewhat different: the Basin area $(0.0421$, $16.8)$ - the Dvina Bay $(0.0205,9.2)$ - the Solovetskie Islands $(0.0148,3.8)$ - the Mezen' Bay $(0.0146,0.9)$ - the Gorlo area $(0.0089,3.0)$ - the Kandalaksha Bay $(0.0087,0.6)-$ the Voronka area $(0.0023,3.1)$ - the Onega Bay $(0.0019,0.3)$ - the Chupa Bay $(0.0011$, 0.001) (Table 2).

Thus, the process of water exchange across the region boundaries ensures the input of $\mathrm{N}$ and $\mathrm{P}$ forms in each region, and their output by the water masses. These counter flows, estimated per unit of the water volume, are calculated separately, and it is possible to compare the net effect of water exchange for each region. The ratios of annual input and loss values of $\mathrm{N}_{\text {tot }}$ and $\mathrm{P}_{\text {tot }}$, which are provided by the water exchange through the boundaries of each region with neighboring areas of the White Sea, were estimated. The excess of the $\mathrm{N}_{\text {tot }}$ input during the water exchange through the borders of neighboring regions is higher than its losses for the Basin, the Mezen' Bay and the Onega Bay (respectively in $6.2,4.7$, and 2.2 times). For the other regions, the ratio value of the annual input to the loss of $\mathrm{N}$ at the water exchange is $<1$ (for the Gorlo area, and the Solovetsky Islands - by 0.7; for the Kandalaksha Bay - 0.5; for the Chupa Bay - 0.3; for the Dvina Bay, and the Voronka area - by 0.1 ).

Excess of the $\mathrm{P}_{\text {tot }}$ input of over its losses during the water exchange takes place for the Chupa Bay, the Onega Bay, the Mezen' Bay, and the Gorlo area (respectively, in 39.8, 7.9, 4.6, and 2.6 times). For the Kandalaksha Bay, the ratios of the annual $\mathrm{P}_{\text {tot }}$ input and output at the water exchange are equal, and for other regions the ratio of these $\mathrm{P}_{\text {tot }}$ fluxes is $<1$ (for the Basin -0.8 , the Solovetskie Islands and the Voronka area -0.7 , and the Dvina Bay - 0.5).

Different components (both chemical BS forms and biomass of organisms including $\mathrm{N}$ and $\mathrm{P}$ ) participate in the transfer at the water exchange through the boundaries of the regions. The contributions of these variables, estimated per unit of the water volume, as well as in the input and output through the region boundaries at the water exchange are 
different. The relative contribution to the loss of DON during the water exchange through the boundaries of regions 1-9 are, respectively, 9.1, 6.4, 37.0, 3.9, 29.4, 7.1, 58.1, 26.6, and $33.9 \%$. Similar contributions to ND losses for the same regions are 53.5, 0.3, 43.5, $7.6,43.4,43.8,25.8,53.3$, and $54.0 \%$. The relative losses of $\mathrm{NO}_{3}$ in the water exchange through the boundaries of some regions have been increased and equal: $21.8 \%$ in the Kandalaksha Bay, 66.1\% in the Onega Bay, $47.8 \%$ in the Mezen' Bay, $11.8 \%$ in the Chupa Bay, $32.7 \%$ in the Solovetskie Islands, and $8.2 \%$ in the Gorlo area. The relative losses of biomass in the water exchange are: $F 1 \mathrm{~N}-9.8 \%$ in the Basin area; $F 2 \mathrm{~N}-11.0 \%$ in the Onega Bay; $F 3 \mathrm{~N}-12.2 \%$ in the Mezen Bay; and $Z 1 \mathrm{~N}-6.3 \%$ in the Gorlo area.

Significant differences are noted in the relative loss of $\mathrm{P}$ forms during the water exchange across the region boundaries. So, in the Kandalaksha Bay, the losses of DOP, PD, and DIP are 36.1, 15.9, and 27.3\%; in the Dvina Bay - 28.3, 32.2, and 11.6\%; in the Solovetskie Islands $-32.2,20.3$, and 25.4\%; in the Basin area - 48.2, 17.2, and 18.9\%. The water exchange defines the significant losses of DIP (49.7\%) in the Onega Bay; DOP and DIP (23.3 and 38.6\%) in the Mezen' Bay; DOP and PD (16.8 and 27.2\%) in the Gorlo area, and (7.8 and $62.2 \%)$ in the Voronka area. It should also be recognized that the role of $\mathrm{P}$ output in the biomasses of organisms is significant: for the phytoplankton $F 1$ - in the Voronka area (14.2\%); in the Basin area (11.6\%), and in the Gorlo area (8.6\%); for the phytoplankton $F 2$ and $F 3$ - in the Chupa Bay (43.9, and 21.9\%), and in the Onega Bay (24.3, and 13.5\%); for the zooplankton $Z 1$ - in the Gorlo area (33.4\%), the Chupa Bay (27.2\%), and Dvina Bay (14.5\%); and for the zooplankton Z2 - in the Dvina Bay (14.5\%), in the Mezen' Bay (11.7\%), and in the Gorlo area (11.4\%).

\section{BS removal at the water exchange from the White Sea (Voronka area) to the Barents Sea}

The estimated annual outputs of $\mathrm{N}_{\text {tot }}$ and $\mathrm{P}_{\text {tot }}$ during the water exchange across the border of the White Sea (the Voronka area) with the Barents Sea are respectively 0.0633 $\mathrm{g} \mathrm{N} /\left(\mathrm{m}^{3} \times\right.$ year $), 85.3$ thousand tons of $\left.\mathrm{N}\right)$ and $0.0167 \mathrm{~g} \mathrm{P} /\left(\mathrm{m}^{3} \times\right.$ year $), 22.5$ thousand tons of P) (Table 1, and 2). Thus, the Barents Sea serves as a source of BS for the White Sea: the annual influx of $\mathrm{N}_{\text {tot }}$ and $\mathrm{P}_{\text {tot }}$ from the Barents Sea to the White Sea, calculated per unit of the volume in the Voronka area, is 1.5 times higher in water exchange than the loss of substances during removal by the water masses from the White Sea to the Barents Sea.

The distribution of the main losses of the $\mathrm{N}$ compouns $\left(\mathrm{g} \mathrm{N} /\left(\mathrm{m}^{3} \times\right.\right.$ year $\left.)\right)$ during the water exchange between the White Sea with Barents Sea is represented by the following indicators: DON -0.0342 (or 54.0\%), ND - 0.0105 (16.6\%), F1N $-0.0039(6.1 \%), \mathrm{NO}_{3}$ and $B 1 \mathrm{~N}-0.0037$ (5.8\% each), $Z 1 \mathrm{~N}-0.0034$ (5.4\%). The remaining forms of $\mathrm{N}$ are $0.0002-00017(0.4-2.7 \%)$. Calculations show that output of the main forms of $\mathrm{N}$ (DON and ND) during the water exchange from the White Sea to the Barents Sea is 1.3 and 4.8 times higher, respectively, than their input with a reverse water flow. However, the net effect of the water exchange in forms of $\mathrm{N}$ shows the excess of its supply from the Barents Sea (by $0.0353 \mathrm{~g} \mathrm{~N} /\left(\mathrm{m}^{3} \times\right.$ year), by 46.7 thousand tons of $\left.\mathrm{N}\right)$. 
For the $\mathrm{P}$ forms, the loss pattern (in $\mathrm{g} \mathrm{P} /(\mathrm{m} 3 \times$ year), thousand tons of $\mathrm{P}$ ) in the water exchange from the White Sea to the Barents Sea is characterized by the following indicators: DOP and DIP - $(0.0038,5.1)(22.5 \%$ each), PD - 0.0055, 7.4 (32.8\%), Z1P and $Z 2 \mathrm{P}-0.0016,2.2$ (9.8\% each); the remaining $\mathrm{P}$ forms are $0.2-0.9 \%$. The comparison shows that the input of dissolved forms of P (DOP and DIP) when exchanged from the Barents Sea to the White Sea is higher than their losses when removed from the White Sea by a counter water flow.

\section{BALANCES OF N AND P COMPOUNDS IN THE REGIONS OF THE WHITE SEA}

Based on the results of calculations of the incoming and outgoing parts of the $\mathrm{N}$ and $P$ fluxes, the values of their balances per unit of the water volumes were calculated (in $g$ Element $/\left(\mathrm{m}^{3} \times\right.$ year $)$ ) and for the whole water volume (in thousand tons of Element/year) of regions and in the White Sea as a whole (Tables 1 and 2).

In regions 1-9 of the White Sea, the calculated values of the annual input / output of $\mathrm{N}$ (in $\mathrm{g} \mathrm{N} /\left(\mathrm{m}^{3} \times\right.$ year), thousand tons of $\mathrm{N}$ ) were in: the Kandalaksha Bay (2.7678, $197.1 / 2.1361,152.1)$ - the Onega Bay $(2.3219,316.9$ / 2.2498, 307.1) - the Dvina Bay (5.3774, 2419.8 / 4.0098, 1804.4) - the Mezen' Bay (3.0044, 177.3 / 2.6086, 153.9) the Solovetskie Islands $(2.5512,652.6$ / 2.1494, 549.8) - the Basin area $(1.9404,773.9$ / $0.5898,235.2)$ - the Gorlo area $(2.0402,690.0 / 1.8553,627.5)$ - the Voronka area $(2.2308$, $3004.9 / 1.7497,2356.9)$ - the Chupa Bay $(3.0482,3.5 / 2.9507,3.4)$. For the unit of the water volume, the largest annual $\mathrm{N}$ input and output were recorded for the Dvina Bay, and the lowest ones - for the Basin area (Table 1).

For the regions 1-9 of the White Sea, the estimated discrepancies in the balance of $\mathrm{N}$ per unit of the water volume (in $\mathrm{g} \mathrm{N} /\left(\mathrm{m}^{3} \times\right.$ year$\left.), \%\right)$ are: the Kandalaksha Bay $(0.6317$, $22.8)$ - the Onega Bay $(0.0722,3.1)$ - the Dvina Bay $(1.3675,25.4)$ - the Mezen' Bay $(0.3959,13.2)$ - the Solovetskie Islands $(0.4018,15.7)$ - the Basin area $(1.3506,69.6)$ - the Gorlo area $(0.1849,9.1)$ - the Voronka area $(0.4811,21.6)$ - the Chupa Bay $(0.0974 ; 3.2)$. The range of the calculated residual of the $\mathrm{N}$ balance for the regions of the White Sea is $3.1-69.6 \%$ (the lowest is for the Onega Bay, the largest one for the Basin area). The average discrepancy in the $\mathrm{N}$ balance for all sea regions is $20.4 \%$ (Table 1 ).

Estimated input / output of $\mathrm{P}\left(\mathrm{g} \mathrm{P} /\left(\mathrm{m}^{3} \times\right.\right.$ year $)$, thousand tons of $\left.\mathrm{P}\right)$ in regions 1-9 of the White Sea are: the Kandalaksha Bay $(1.2032,85.7$ / 0.9616, 68.5) - the Onega Bay $(1.0618,144.9$ / 0.9746, 133.0) - the Dvina Bay $(2.2118,995.3$ / 1.8394, 827.7) the Mezen' Bay $(1.1586,68.4$ / 0.9998, 59.0) - the Solovetskie Islands (1.0983, 280.9 / $0.9689,247.8)$ - the Basin are $(0.7013,279.7 / 0.4383,174.8)$ - the Gorlo area $(0.6383$, 215.9 / 0.5633, 190.5) - the Voronka area $(0.6007,809.1 / 0.5549,747.4)$ - the Chupa Bay $(0.9686,1.1 / 0.9401,1.1)$. For a year, the inflow and losses of $\mathrm{P}$ are greatest for the Dvina Bay, the lowest - for the Basin area (Table 2).

In the regions of the White Sea, the estimated discrepancies in the $\mathrm{P}$ balance (in $\mathrm{g} \mathrm{P} /\left(\mathrm{m}^{3} \times\right.$ year), \%) are: the Kandalaksha Bay $(0.2416,20.1)$ - the Onega Bay $(0.0637$, 
$6.1)$ - the Dvina Bay $(0.3734,16.9)$ - the Mezen' Bay $(0.1588,13.7)$ - the Solovetskie Islands $(0.1313,12.0)$ - the Basin area $(0.2630,37.5)$ - the Gorlo area $(0.0750,11.8)-$ the Voronka area $(0.0457 ; 7.6)$ - the Chupa Bay $(0.0285,2.9)$. The total range of the calculated discrepancies of the $\mathrm{P}$ balance for the regions of the White Sea is $2.9-37.5 \%$ (the smallest in the Chupa Bay, and the largest - in the Basin area). The mean discrepancy in the $\mathrm{P}$ balance in all the sea regions is $14.2 \%$ (Table 2).

For each sea region, the same ranges of the balance residuals are obtained in the total water volumes as well as the values per unit of the water volume.

When calculating the balance of $\mathrm{N}$ and $\mathrm{P}$ for the White Sea as a whole, the transfer of the $\mathrm{N}$ and $\mathrm{P}$ forms was not taken into account for the water exchange between neighboring sea areas since the fractions $\mathrm{N}$ and $\mathrm{P}$ participating in the transport are within the total sea area (Table 1).

The total $\mathbf{N}$ income in the input component of its balance was equal to 8042.1 thousand tons of $\mathrm{N} / \mathrm{year}$. This amount includes the contributions of the following processes (thousand tons of $\mathrm{N} / \mathrm{year}$ ):

- receipt of the $\mathrm{N}$ forms with the river runoff (144.1) and from the Barents Sea (132.7) - the total income is 276.8 (or $3.4 \%$ of total revenues);

- formation of detritus ND - 4002.6 (or $49.8 \%$ );

- transformation of detritus ND to DON - 1750.0 (or 21.8\%);

- metabolic $\mathrm{N}$ excretion by the organisms of community -1159.5 (or $14.4 \%$ );

- receipt with anthropogenic pollution sources -837.0 (or $10.4 \%$ );

- receipts with atmospheric precipitation -16.2 (or $0.2 \%$ ).

The total $\mathbf{N}$ losses in the output component of its balance was equal to 5996.5 thousand tons of N/year, and this number includes estimated losses as a result of the following processes (thousand tons of $\mathrm{N} /$ year):

- consumption by the bacteria $B 1 \mathrm{~N}-511.9$ (or $8.5 \%$ of all losses);

- consumption by the phytoplankton $F 1 \mathrm{~N}-890.1$ (or $14.8 \%$ );

- consumption by the phytoplankton $F 2 \mathrm{~N}-40.8$ (or $0.7 \%$ );

- consumption by the phytoplankton $F 3 \mathrm{~N}-41.9$ (or $0.7 \%$ );

- consumption by the zooplankton $Z 1 \mathrm{~N}-1047.9$ (or $17.5 \%$ );

- consumption by the zooplankton $Z 2 \mathrm{~N}-420.6$ (or $7.0 \%$ );

- consumption by macrophytes $M K \mathrm{~N}-1822.2$ (or $30.4 \%$ );

- sedimentation of the detritus ND - 1135.9 (or 19.0\%);

- removal to the Barents Sea from the Voronka area (the White Sea) 85.2 (or $1.4 \%$ ).

The residual of the N balance for the White Sea as a whole is 2045.4 thousand tons of N/year (or 25.4\%) (Table 1).

The total income of $\mathbf{P}$ in the input side of the balance sheet equal to 2839.7 thousand tons of $\mathrm{P} /$ year, and it includes the contributions from the following processes (thousand tons of $\mathrm{P} /$ year):

- receipt of P forms with river runoff (13.0) and from the Barents Sea (34.1) the total income is 47.1 (or $1.7 \%$ of total revenues); 
- formation of the detritus PD - 1562.6 (or 55.0\%);

- metabolic P excretion by the organisms of community - 660.0 (or $23.3 \%$ );

- transformation of detritus PD to DOP - 542.8 (or 19.1\%);

- receipt with anthropogenic pollution sources -26.4 (or $0.9 \%$ );

- receipts with the atmospheric precipitation -0.8 (or $<0.1 \%$ ).

The total $\mathrm{P}$ losses in the output part of its balance equal to 2411.0 thousand tons of $\mathrm{P} /$ year, taking into account the calculated values of the $\mathrm{P}$ losses for the following processes (thousand tons of $\mathrm{P} / \mathrm{year}$ ):

- consumption by the bacteria $B 1 \mathrm{P}-91.9$ (or $3.8 \%$ of all losses);

- consumption by the phytoplankton $F 1 \mathrm{P}-281.7$ (or $11.7 \%$ );

- consumption by the phytoplankton $F 2 \mathrm{P}-8.9$ ( or $0.3 \%$ );

- consumption by the phytoplankton $F 3 \mathrm{R}-6.6$ (or $0.3 \%$ );

- consumption by the zooplankton Z1P - 578.4 (or $24.0 \%$ );

- consumption by the zooplankton Z2P - 334.4 (or $13.9 \%$ );

- consumption by macrophytes $M K \mathrm{R}-896.9$ (or $37.2 \%$ );

- sedimentation of detritus PD - 189.7 (or 7.9\%);

- P removal to the Barents Sea from the Voronka area (the White Sea) - 22.5 (or 0.9\%).

The residual of the $\mathrm{P}$ balance for the White Sea as a whole is 428.4 thousand tons of $\mathrm{P} /$ year (or $15.1 \%$ ) (Table 2 ).

\section{CONCLUSIONS}

Mathematical modeling based on system analysis is the most promising modern methodology for studying the state and the functioning of marine ecosystems. This study is an example of obtaining a new information for a marine reservoir based on accumulated long-term oceanographic data with the help of the CNPSi-model (for nine different regions of the White Sea with a given horizontal water exchange between adjacent regions, the flow of river runoff into six marine bays, the bilateral water exchange with the Barents Sea and a single-layered vertical structure of the marine environment for all regions of the White Sea).

According to calculations on the CNPSi-model of the dynamics of individual forms of $\mathrm{N}\left(\mathrm{DON}, \mathrm{ND}, \mathrm{NH}_{4}, \mathrm{NO}_{2}, \mathrm{NO}_{3}, B 1 \mathrm{~N}, F 1 \mathrm{~N}-F 3 \mathrm{~N}, Z 1 \mathrm{~N}-Z 2 \mathrm{~N}, M K \mathrm{~N}\right)$ and of $\mathrm{P}(\mathrm{DOP}, \mathrm{PD}$, DIP, $B 1 \mathrm{P}, F 1 \mathrm{P}-F 3 \mathrm{P}, Z 1 \mathrm{P}-\mathrm{Z} 2 \mathrm{P}, M K \mathrm{P})$, the annual balances of the external and internal BS fluxes were compiled, which were taken into account in the model calculations to reveal their role in the BS dynamics (compounds of N and P). Since the uniform dimensions for the concentrations of the $\mathrm{N}$ compounds $(\mathrm{mg} \mathrm{N} / \mathrm{L}$ ) and the $\mathrm{P}$ compounds (mg P/L) are used, it is possible to compare their common $\mathrm{N}$ and $\mathrm{P}$ fluxes, related to their inputs and outputs in calculating the balance of the elements. The balances are expressed as total values of the $\mathrm{N}_{\text {tot }}$ and $\mathrm{P}_{\text {tot }}$ fluxes for different regions of the White Sea, estimated from the results of calculations, which allowed us to obtain the final annual picture of the effect of the total fluxes of elements on the BS dynamics in different regions and the White Sea as a whole. 
The components of the annual values of $\mathrm{N}_{\text {tot }}$ and $\mathrm{P}_{\text {tot }}$ balances are estimated in two dimensions -1 . per unit of the water volume (in $\mathrm{g} \mathrm{N} /\left(\mathrm{m}^{3} \times\right.$ year) and $\mathrm{g} \mathrm{P} /\left(\mathrm{m}^{3} \times\right.$ year) ), and 2. for the entire volume of the water column (thousand tons of $\mathrm{N} /$ year and thousand tons of $\mathrm{P} /$ year). Dimension 1 allows us to compare the values of balances for individual regions of the sea, and dimension 2 - illustrates the real BS fluxes taking into account the water volumes in each region and in the White Sea as a whole.

The input component of the BS balance takes into account the revenues to each sea area of $\mathrm{N}_{\text {tot }}$ and $\mathrm{P}_{\text {tot }}$ from the external sources (river runoff, atmospheric precipitation, anthropogenic pollution, from the Barents Sea), and also due to internal processes in the ecosystem ( $\mathrm{N}$ and $\mathrm{P}$ transformations, their circulation / repeated recycling in the marine environment due to the products of vital activity - metabolic BS excretions and the detritus formation). The share of $\mathrm{N}$ fluxes, determined by external sources, on average in the sea regions ranges from $0.5-8.1 \%$, and by internal ones $-13.8-49.9 \%$; for these $\mathrm{P}$ fluxes the ranges are respectively $0.2-4.2 \%$ and $22.9-53.8 \%$.

The most significant sources of $\mathrm{N}_{\text {tot }}$ and $\mathrm{P}_{\text {tot }}$ input are internal BS fluxes associated with the vital activity of the organisms of community - with the formation of detritus, its subsequent transformation to organic components (DON and DOP) and the total metabolic BS excretions into the marine environment. For each area of the White Sea, the relative contribution of these processes to the common pool of the BS stock in a unit of water volume has its own characteristic values. For example, the share of the detrite ND formed in a year is the largest in the total contribution of other processes, and for regions $1-9$ it is $53.3 \%, 48.1,52.5,49.8,56.5,37.5,50.5,45.9$, and $54.8 \%$, respectively, and for PD $-50.6 \%, 56.7,53.9,48.2,55.5,48.1,59.9,55.5$, and 56.0\%. The smallest proportion of the ND and PD formed is in the Basin area, and the largest - in the Chupa Bay (ND) and the Onega Bay (PD).

The proportion of DON in the ND transformation in the mass of the $\mathrm{N}_{\text {tot }}$ formed is somewhat lower: $26.4 \%, 22.7,26.5,17.9,20.8,19.2,14.3,18.9$, and $15.9 \%$ respectively in the regions 1-9; and for the DOP - 23.9\%, 18.8, 22.7, 13.3, 18.5, 23.7, 15.3, 14.8, and $10.5 \%$ of the mass of the $\mathrm{P}_{\text {tot }}$ formed. The smallest proportion of DON formation is in the Gorlo area, and the largest - in the Dvina Bay, and according to DOP - respectively on the Chupa Bay and the Kandalaksha Bay.

The relative contribution of the excreted metabolites to the internal stock of $\mathrm{N}_{\text {tot }}$ and $\mathrm{P}_{\text {tot }}$ (or the proportion of $\mathrm{N}$-containing metabolites in the regions of the White Sea) is changing within 10.1-15.7\% (the smallest in the Basin area and the largest - in the Voronka), and the proportion of P-containing metabolites - is in the range of 20.9-26.1\% (the lowest - in the Kandalaksha Bay and the largest - in the Chupa Bay).

The relative contribution of other sources of $\mathrm{N}_{\text {tot }}$ and $\mathrm{P}_{\text {tot }}$ to the regions of the White Sea is generally small. The share of the river runoff in the $\mathrm{N}_{\text {tot }}$ input is $0.5-7.5 \%$ (the low value falls on the Kandalaksha Bay, and the high one - on the Chupa Bay), while in the $\mathrm{P}_{\text {tot }}$ it is $0.03-10.4 \%$ (the lowest - for the Solovetskie Islands and the largest - for the Mezen' Bay).

The load on $\mathrm{N}_{\text {tot }}$ and $\mathrm{P}_{\text {tot }}$ to the regions of the White Sea due by the anthropogenic impact (wastewater discharges) was estimated from the results of various calculation op- 
tions in comparison with the received BS data with river runoff in the spring. The relative contribution of the annual discharge of sewage, as a BS load source, is comparable to the load provided by river runoff in the regions of $1-5$ and 9 of the White Sea. In general, the BS input from wastewater discharges accounts for 3.0-6.6\% and $0.6-1.9 \%$ of the total annual supply of $\mathrm{N}_{\text {tot }}$ and $\mathrm{P}_{\text {tot }}$, respectively, from all other sources (the lowest value is in the Dvina Bay, the largest one - in the Basin area (according to N) and in the Chupa Bay (according to $\mathrm{P}$ ).

The comparison of the contribution values of the river runoff and the water exchange through the region boundaries in the BS supply: the share of the water exchange in the $\mathrm{N}$ load varies within $0.1-15.9 \%$, and in P load $-0.2-5.8 \%$ (the lowest in the Voronka area, and the largest - the Basin (for N), and in the Mezen' Bay (for P)). The relative contribution of the BS input from the Barents Sea to the White Sea (the BS load for the Voronka area) is comparable to the greatest impact of river runoff on the BS removal: for $\mathrm{N}_{\text {tot }}$ this contribution is $4.4 \%$, and for $\mathrm{P}_{\text {tot }}-4.2 \%$.

For the regions of the White Sea, the relative contribution of atmospheric precipitation, as a source of BS, is the lowest of all sources and it is: for the $\mathrm{N}_{\text {tot }}-<0.1-1.3 \%$ and for the $\mathrm{P}_{\text {tot }}-<0.01-1.1 \%$. The smallest relative contribution of this source is fixed according to the $\mathrm{N}$ - for the Mezen' Bay, and to the $\mathrm{P}-$ for the Basin and Gorlo areas, and the largest - for the Chupa Bay (for $\mathrm{N}$ and $\mathrm{P}$ ).

The greatest impact on the reduction of total concentrations of $\mathrm{N}_{\text {tot }}$ and $\mathrm{P}_{\text {tot }}$ in the regions of the White Sea is provided by a community of organisms that actively participates in the BS transformations. The main losses of organic and mineral forms of $\mathrm{N}$ and $\mathrm{P}$ occur at the BS consumption processes, as a result of which the organisms form their biomass and maintain it in the active state during a year. In the regions of the White Sea, the intensity of the biomass formation by organisms and their activity depends on the influence of external factors of the environment (temperature, light intensity, transparency of water, BS input from the external sources).

The general characteristics of the expenditure part of the $\mathrm{N}_{\text {tot }}$ and $\mathrm{P}_{\text {tot }}$ balances includes estimates of contributions of individual processes to the relative BS losses in regions of the White Sea. The greatest contribution to the relative losses of $\mathrm{N}_{\text {tot }}$ and $\mathrm{P}_{\text {tot }}$ is caused by macrophytes $M K$ and the living organisms in the water environment $(B 1, F 1$, $F 2, F 3, Z 1$, and $Z 2$ ). Since the effect of macrophytes $M K$ is not taken into account in the deepwater Basin area, one can imagine their relative contribution to the consumption of individual $\mathrm{N}$ and $\mathrm{P}$ forms separately for other regions of the sea: in relation to the total $\mathrm{N}_{\text {tot }}$ losses, this contribution varies from 68.9-71.6\% (in the Gorlo area, the Chupa Bay, the Voronka area, and the Mezen' Bay) to 77.9-85.6\% (in the Onega Bay, the Solovetskie Islands, the Kandalaksha Bay, the Basin area, the Dvina Bay). The relative contribution of the $\mathrm{P}$ consumption to the total losses of $\mathrm{P}_{\text {tot }}$ varies from 30.4-33.5\% (in the Voronka area, the Chupa Bay, and the Gorlo area) to 40.2-48.8\% (in the Solovetskie Islands, the Mezen' Bay, the Onega Bay, the Dvina Bay, and the Kandalaksha Bay).

Without taking into account the role of macrophyte $M K$, the relative contribution of the organisms of the lower trophic links to $\mathrm{N}$ loss for the some sea regions varies from 
57.7-63.3\% (the Mezen' Bay, the Gorlo area, the Onega Bay, the Chupa Bay, and the Voronka area), and to $70.1-85.2 \%$ (the Kandalaksha Bay, the Solovetskie Islands, the Dvina Bay, and the Basin area), and to the P loss - from 68.6-72.9\% (the Mezen' Bay, and the Onega Bay), to $80.4-86.3 \%$ (the Chupa Bay, the Kandalaksha Bay, the Solovetskie Islands, the Voronka area, the Basin area, and the Dvina Bay), and up to $97.2 \%$ (the Gorlo area).

The sedimentation of detritus forms (ND and PD) is a significant process affecting the relative losses of $\mathrm{N}_{\text {tot }}$ and $\mathrm{P}_{\text {tot }}$. According to the regions of the White Sea, the relative role of this process varies: for ND - from 6.4\% (the Basin area) to $11.0-15.1 \%$ (the Dvina and Kandalaksha Bays, and the Solovetskie Islands), and to 21.4-26.9\% (the Onega Bay, the Gorlo and Voronka areas, the Chupa and Mezen' Bays), and for PD - from 0.3\% (the Gorlo area) to 5.6-6.2\% (the Basin area, and the Dvina Bay), to 8.7-9.6\% (the Kandalaksha Bay, the Voronka area, and the Solovetskie Islands), and to $13.2-16.7 \%$ (the Chupa, Onega and Mezen' Bays).

A less significant process, which determines the relative losses of $\mathrm{N}_{\text {tot }}$ and $\mathrm{P}_{\text {tot }}$, is the current transfer of different forms of $\mathrm{N}$ and $\mathrm{P}$ into neighboring regions of the sea. The relative losses in the removal of $\mathrm{N}$ forms are increased in the Gorlo and the Basin areas $(7.8-8.5 \%)$, and the $\mathrm{P}$ forms in the Basin area (9.6\%). In other regions, these relative losses are significantly lower: for $\mathrm{N}-0.6-3.4 \%$, and for $\mathrm{P}-0.1-1.6 \%$. The relative losses of $\mathrm{N}$ and $\mathrm{P}$ due to the water transfer in the Barents Sea from the White Sea (Voronka area) are also small: 3.6 and $0.9 \%$ of the total losses of $\mathrm{N}_{\text {tot }}$ and $\mathrm{P}_{\text {tot }}$ respectively.

For the White Sea as a whole, the balance of $\mathrm{N}$ and $\mathrm{P}$ is calculated on the basis of the components estimated for individual sea regions (respectively, in thousand tons of $\mathrm{N}$ and thousand tons of $\mathrm{P}$ ). The smallest supply of $\mathrm{N}$ and $\mathrm{P}$ in the sea is provided for a year by atmospheric precipitation -16.2 thousand tons of $\mathrm{N}$ and 0.8 thousand tons of $\mathrm{P}$ (or $<0.1 \%$ of total $\mathrm{N}$ and $\mathrm{P}$ receipts from all sources). To the different regions of the sea, the annual BS inputs with the river runoff were 144.0 and 13.0 thousand tons of $\mathrm{N}$ and $\mathrm{P}$ respectively (or $1.8 \%$ of $\mathrm{N}_{\text {tot }}$ and $0.5 \%$ of $\mathrm{P}_{\text {tot }}$ ). From the Barents Sea to the White Sea, the $\mathrm{N}$ input is 132.7 thousand tons of $\mathrm{N}$ (or $1.7 \%$ of $\mathrm{N}_{\text {tot }}$ from all sources), and the $\mathrm{P}$ input 34.1 thousand tons of $\mathrm{P}$ (or $1.2 \%$ of $\mathrm{P}_{\text {tot }}$ from all sources).

Total amounts of $\mathrm{N}$ and $\mathrm{P}$, entering to the marine environments with polluted sewage waters, are respectively 837.0 and 26.4 thousand tons of $\mathrm{N}$ and $\mathrm{P}$ respectively (or 10.4 and $0.9 \%$ of total inputs of these elements to the sea water). The main quantity of $\mathrm{N}$ and $\mathrm{P}$ is formed by organisms as a result of the recycling and repeated BS turnover in the water environment: by metabolic excretions - 1159.5 thousand tons $\mathrm{N}(14.4 \%)$ and 660.0 thousand tons $\mathrm{P}(23.3 \%)$, as well as the detritus -4002.6 thousand tons of detrital $\mathrm{N}(49.8 \%)$ and 1562.6 thousand tons of detrital P (55.0\%).

The main losses of $\mathrm{N}$ and $\mathrm{P}$ are provided by the organisms of the lower trophic links (bacteria, phytoplankton and zooplankton) and macrophytes using the $\mathrm{N}$ and $\mathrm{P}$ compounds as sources of nutrition and energy for the biomass creation. The contribution of different organisms to the $\mathrm{N}$ and $\mathrm{P}$ uptake is different (thousand tons of Element, $\%$ of total uptake): the bacteria $B 1$ uptake of $\mathrm{N}-511.9,8.5$; and of $\mathrm{P}-91.9,3.8$; the diatom phytoplankton $F 1$ uptake of $\mathrm{N}-890.1,14.8$; and of $\mathrm{P}-281.7,11.7$; the zooplankton $Z 1$ uptake 
of $\mathrm{N}-1047.9,17.5$; and of $\mathrm{P}-578.4,24.9$; macrophytes $M K$ uptake of $\mathrm{N}-1822.2,30.4$; and of $\mathrm{P}-896.9,37.2$. The remaining organisms $(F 2, F 3, Z 2)$ consume $40.8-420.6$ thousand tons of $\mathrm{N}(0.7-7.0 \%)$ and 6.6-344.4 thousand tons of $\mathrm{P}(0.3-13.9 \%)$. Losses of $\mathrm{N}$ and $\mathrm{P}$ on the sedimentation of detritus (ND and PD) are 1135.9 thousand tons $\mathrm{N}(19.0 \%)$ and 189.7 thousand tons $\mathrm{P}(7.9 \%)$, respectively. The BS losses at the water transfer from the White Sea to the Barents Sea are 85.2 thousand tons of N $(1.4 \%)$ and 22.5 thousand tons of $\mathrm{P}$ ( or $0.9 \%)$.

The total $\mathrm{N}$ and $\mathrm{P}$ supply from all the sources considered in the White Sea is estimated at 8042.1 thousand tons $\mathrm{N}$ and 2839.7 thousand tons $\mathrm{P}$, respectively, with the $\mathrm{N}$ : P ratio of 5.1:1. The total losses of $\mathrm{N}$ and $\mathrm{P}$ for the White Sea are generally estimated in 5996.5 thousand tons of $\mathrm{N}$ and 2411.0 thousand tons of $\mathrm{P}$ (ratio of removal $\mathrm{N}: \mathrm{P}=2.5: 1$ ). In general, for the White Sea, the residual balance for $\mathrm{N}$ is 2045.6 thousand tons $\mathrm{N} / \mathrm{year}$ (or $25.4 \%$ ), and for $\mathrm{P}-428.4$ thousand tons $\mathrm{P} /$ year (or $15.1 \%$ ).

However, the data analysis using mathematical modeling has its limitations, and not every marine water body can be investigated on the basis of the mathematical modeling methodology. These limitations are connected, on the one hand, with the available research data (or with the study of the marine object), and, on the other hand, the capabilities of the mathematical model (not all features of the marine ecosystem can be investigated using a specific model). The capabilities of the CNPSi- model are related to the study of the development of intra-annual biotransformation of BS, which are regulated by the values of the morphometric parameters of the studied water system, the factors of the marine environment (temperature, light intensity, transparency, nutrient loading, the impact of anthropogenic sources) and water regime indicators. The maximum permissible in this model is the simultaneous study of 10 regions of the sea, two layers along the vertical and the upper layer of bottom sediments, that is possible with an appropriate study of the water body.

Using the simplified description of the vertical structure, the results of calculations on the CNPSi model revealed differences in the characteristics determining the biohydrochemical portrait of the ecosystem of the White Sea (by the example of its nine regions), namely, in the intra-annual dynamics of concentrations of BS and biomass of organisms participating in their biotransformation. According to the calculated parameters of external and internal BS fluxes, balances of $\mathrm{N}$ and $\mathrm{P}$ compounds for individual regions and the White Sea as a whole were compiled for such a simplified description of the vertical structure of the marine environment.

In the future, it is planned to repeat this study with the specification of horizontal transfer conditions for the two-layer vertical structure of the White Sea. The long-term plan for the improvement of the CNPSi model involves the introduction of a horizon cycle so that it can be used as a tool to study the features of the variation over a year of the vertical distribution of chemical and biological variables, depending on the complex of factors affecting different regions of the sea.

This study was carried out within the framework of the state task of the Shirshov Institute of Oceanology Russian Academy of Sciences (theme No. 0149-2018-0015). 


\section{References}

Ecological atlas of Russia. Moscow: Publ. House Map, 2002, 128 p. (Ekologicheskij atlas Rossii. Moskva: Karta, 2002, 128 p.), (In Russian).

Elisov V. V. Evaluation of the water, thermal and salt balances of the White Sea. (Ocenka vodnogo, termicheskogo i solevogo balansov Belogo moria), Meteorology and Hydrology, 1997, No. 9, pp. 83-93, (In Russian).

Gosudarstvennyj doklad o sostoyanii okruzhaushej sredy Respubliki Kareliya v 2011 g. (State report on the state of the environment of the Republic of Karelia in 2011), Petrozavodsk: Min-vo po prirodopol'zovaniu i ekologii Respubliki Kapeliya, 2012, 294, (In Russian).

Gosudarstvennyj doklad o sostoyanii okruzhaushej sredy Respubliki Kareliya v 2012 g. (State report on the state of the environment of the Republic of Karelia in 2012), Petrozavodsk: Min-vo po prirodopol'zovaniu i ekologii Respubliki Kapeliya, 2013, 328 p., (In Russian).

Gosudarstvennyj doklad o sostoyanii okruzhaushej sredy Respubliki Kareliya v 2013 g. (State report on the state of the environment of the Republic of Karelia in 2013), Petrozavodsk: Min-vo po prirodopol'zovaniu i ekologii Respubliki Kapeliya, 2014, 200 p., (In Russian).

Il'yash L.V., Zhiitina K.S., and Fedorov V.D. Fitoplankton Belogo morya. (Phytoplankton of the White Sea). Moskva: “Janus-K”, 2003, 168 p., (In Russian).

Jagov G.V. Control of the content of nitrogen compounds in wastewater treatment. Water supply and sanitary engineering, 2008, No. 7, pp. 45-52. (Original Russian Paper: Jagov G.V. Control' soderzhaniya soedinenij azota pri ochistke stochnyh vod, Vodosnabzhenie $i$ sanitarnaya tehnika, 2008, No. 7, pp. 45-52), (In Russian).

Kadashova N.A. Fizico-geograficheskie aspecty prorodopol'zovaniya v Belom more. (Physicogeographical aspects of the nature use in the White Sea), Author's Abstract of disser.... cand. geograph. sciences, 2011, 175 p., (In Russian).

Kotova E.I., Krasavina A.S., and Sobolevskaya A.P. Beloe more. Kachestvo morskih vod po gidrohimicheskim pokazatelyam. Ezhegodnik 2015. (The White Sea. Quality of marine water on the hydrochemical indicators, Yearbook 2015), Ed. Korshenko A.N., Moskva.: Nauka, 2016, pp. 104-109, (In Russian).

Kuznetcov V.V. Beloe more i biologicheskie osobennoctu ego flory i fauny. (The White Sea and the biological features of its flora and fauna), Izvestiya of SSSR Academiya Nauk, 1960, 322 p., (In Russian).

Leonov A.V. Modelirovanie prirodnyh processov na osnove imitacionnoj gidroekologicheskoj modeli transformacii soedinenij C, N, P, Si: uchebnoe posobie. (Modeling of Natural Processes on the Base of Simulation Hydroecological Model of the C, N, P, Si Substance Transformations, Manual Handbook), Uzhno-Sakhalinsk: Sakhalinsk State University, 2012, 148 p., (In Russian).

Leonov A.V., Koltovskaya E.V., and Chicherina O.V. Biohydrochemical Portrait of the White Sea. Computer research and modeling, 2018, Vol. 10, No. 1, pp. 125-160. (Original Russian Paper: Leonov A.V. et al. Biogydrohimicheskij portret Belogo morya. Komp'uternye ussledovaniya i modelirovanie, 2018, Vol. 10, No. 1, pp. 125-160), (In Russian).

Leonov A.V., Semenyak L.V., and Chicherina O.V. Hydrocarbons in the White Sea: Their Inflow and Transformation in the Marine Environment in Different Regions. Water resources, 2017, Vol. 44, No. 1, pp. 78-100, (Original Russian Paper: Leonov A.V. et al. Uglevodorody $\mathrm{v}$ Belom more: ih postuplenie i transformaciya $\mathrm{v}$ morskoj srede $\mathrm{v}$ raznyh rajonah, Vodnye Resursy, 2017, Vol. 44, No. 1, pp. 38-62).

Leonov A.V., Filatov N.N., Zdorovennov R.E., and Zdorovwnnova G.E. Functioning of the White Sea ecosystem: Studying the Transformations of Organogenic Substances Using a Mathematical Model. Water resources, 2004, Vol. 31, No. 5, pp. 511-530, (Original 
Russian Paper: Leonov A.V. et al. Funkcionirovanie ecosistemy Belogo moria: issledovanie na osnove matematicheskoj modeli transformacii organogennyh veshchestv, Vodnye Resursy, 2004, Vol. 31, No. 5, pp. 556-575).

Leonov A.V., Filatov N.N., Zdorovennov R.E., and Zdorovwnnova G.E. Mathematical Modeling of the Ecosystem Functioning Conditions in the Chupa Estuary of the White Sea: Transformation of Organogenic Substances and Bioproductivity of the Marine Environment. Water resources, 2006, Vol. 33, No. 5, pp. 543-567. (Original Russian Paper: Leonov A.V. et al. Matematicheskoe modelirovanie uslovij funkcionirovaniya ecosistemy guby Chupa Belogo morya: transformaciya organogennyh veshchestv i bioproductivnost' morskoj sredy, Vodnye Resursy, 2006, Vol. 33, No. 5, pp. 589-614).

Leonov A.V., Filatov N.N., and Chicherina O.V. Transformation of Organogenic Substances in the White Sea ecosystem: Assessment based on the Results of Mathematical Modeling. Water resources, 2005, Vol. 32, No. 4, pp. 393-409. (Original Russian Paper: Leonov A.V. et al. Transformaciya organogennyh veshchestv v ecosisteme Belogo morya: otsenka po resul'tatam matematicheskogo modelirovaniya, Vodnye Resursy, 2005, Vol. 32, No. 4, pp. 435-451).

Leonov A.V. and Chicherina O.V. Nutrient Transport into the White Sea with River Runoff. Water resources, 2004, Vol. 31, No. 2, pp. 152-173. (Original Russian Paper: Leonov A.V., Chicherina O.V. Vynos biogennyh veshchestv v Beloe more s rechnym stokom, Vodnye Resursy, 2004, Vol. 31, No. 2, pp. 170-192).

Lisicin A.P. Processy v vodosbore Belogo morya: podgotovka, transportirovka i otlozhenie osadochnogo materiala, potoki veshchestva, koncepciya «zhivogo vodosbora». (Processes in the watershed of the White Sea: preparation, transport and deposition of sedimentary material, flows of matter, the concept of a «living catchment»), System of the White Sea, Moskva: Nauchnyj Mir, 2010, Vol. 1, pp. 353-455. (In Russian).

Meybeck M. Carbon, nitrogen, and phosphorus transport by world rivers. Am. J. Sci. 1982, Vol. 282, pp. 401-450.

Moiseenko T.I. Zagriaznenie poverhnostnyh vod vodosbora i kluchevye antropogenno obuslovlennye processy. (Pollution of surface waters of the catchment area and key anthropogenically conditioned processes), System of the White Sea, Moskva: Nauchnyj Mir, 2010, Vol. 1, pp. 301-333 (In Russian).

Nadezhin V.M. Harakternye osobennosti gidrologicheskogo regima Belogo morya. (Characteristic features of the hydrological regime of the White Sea), Trudy PINRO, 1966, Issue 17, pp. 247-248, (In Russian).

Nevesskij E.N., Medvedev V.S., and Kalinenko V.V. Beloe more. Sedimentogenez I istoriya razvitiya $\mathrm{v}$ golocene. (The White Sea. Sedimentogenez and history of development in Holocen), Moskva: Nauka, 1977, 236 p., (In Russian).

Oceanographic conditions and biological productivity of the White Sea. Annotated atlas. (Okeanograficheskie usloviya i biologicheskaya produktivnost' Belogo morya. Annotirovannyj atlas), Murmansk: PINRO, 1991, 115 p., (In Russian).

Tolstikov A.V. Izmenchivost' temperatury poverhnostnogo cloya Belogo moria. (Variability of the surface layer temperature of the White Sea), Moscow: GEOS, 2016, (In Russian).

Zabelina S.A., Vorob'eva T.Ya., Moreva O.Yu., and Tarasova N.A. Ocenka antropogennogo vozdejstviya na sostoyanie ust'evoj oblasti reki Severnaya Dvina. (Assessing the anthropogenic impact on the state of the Northern Dvina mouth area), In «Actual'nye problemy regional'nogo ekologicheskogo monitoringa: nauchnyi i obrazovatel'nyi aspecty. Sb. materialov Vseros, Nauchn. Shkoly (Urgent Problems of Regional Environmental Monitoring: Scientific and Educational Sspects, Mater. All-Russia Sci. School), Kirov: Izd. VyatGTU, 2006, pp. 220-222, (In Russian).

Zalogin B.S. and Kosarev A.N. Morya. (Seas). Moskva: Mysl', 1999, 400 p., (In Russian). 


\title{
ПОКАЗАТЕЛИ БИОГИДРОХИМИЧЕСКОГО ПОРТРЕТА БЕЛОГО МОРЯ: ВНУТРЕННИЕ/ВНЕШНИЕ ПОТОКИ БИОГЕННЫХ ВЕЩЕСТВ, БАЛАНС N И Р
}

\author{
А.В. Леонов ${ }^{1}$, Л.В Семеняк ${ }^{2}$, О.В.Чичерина ${ }^{1}$ \\ ${ }^{1}$ Институт океанологии им. П.П. Ширшова РАН, 117997, Москва, \\ Hахимовский проспект, д.36, e-mail: leonov@ocean.ru, ox_stgr@rambler.ru \\ ${ }^{2}$ Всероссийский научно-исследовательский институт рыбного \\ хозяйства и океанографии 107140 Россия, Москва, ул. Верхняя Красносельская, 17, \\ e-mail:lvsemen@yandex.ru \\ Статья поступила в редакцию 12.09.2018, одобрена к печати 30.11.2018
}

\begin{abstract}
На основе среднемноголетних показателей морской среды (температура, освещенность, прозрачность воды, фотопериод, естественная биогенная нагрузка, нагрузка при воздействии антропогенных источников) с помощью гидроэкологической CNPSiмодели получены для девяти районов Белого моря количественные данные для характеристики биогидрохимического портрета моря. Его основные показатели изменяющиеся в течение года расчетные концентрации органических и минеральных форм N и Р, биомассы организмов низших трофических звеньев (гетеротрофные бактерии, три группы фитопланктона, растительноядный и хищный зоопланктон, макрофиты), которые участвуют в трансформации биогенных веществ. Вычислены также дополнительные показатели портрета - значения положительных и отрицательных внутренних и внешних потоков биогенных веществ, характеризующие в течение года условия развития организмов и трансформации биогенных веществ. Задача данного исследования состояла в получении информации о годовых балансах форм $\mathrm{N}$ и $\mathrm{P}$ на основе расчетных значений внутренних и внешних потоков биогенных веществ для разных районов и Белого моря в целом.
\end{abstract}

Ключевые слова: экосистема Белого моря, биогенные вещества, гетеротрофный бактериопланктон, диатомовый фитопланктон, растительноядный и хищный зоопланктон, макрофиты, детрит, трофическая цепь, CNPSi-модель биотрансформации биогенных веществ, биогидрохимический портрет Белого моря, баланс внутренних и внешних потоков форм $\mathrm{N}$ и $\mathrm{P}$ для девяти районов и Белого моря в целом

\section{Литература}

Государственный доклад о состоянии окружающей среды Республики Карелия в 2011 г. Петрозаводск: Мин-во по природопользованию и экологии РК, 2012. 294 с.

Государственный доклад о состоянии окружающей среды Республики Карелия в 2012 г. Петрозаводск: Мин-во по природопользованию и экологии РК, 2013. 328 с.

Государственный доклад о состоянии окружающей среды Республики Карелия в 2013 г. Петрозаводск: Мин-во по природопользованию и экологии РК, 2014. 300 с.

Елисов В.В. Оценка водного, термического и солевого балансов Белого моря // Метеорология и гидрология. 1997. № 9. С. 83-93.

Забелина С.А., Воробьева Т.Я., Морева О.Ю., Тарасова Н.А. Оценка антропогенного воздействия на состояние устьевой области реки Северная Двина // Актуальные проблемы регионального экологического мониторинга: научный и образовательный аспекты. Материалы Всерос. Научн. школы. Киров: изд-во ВятГТУ, 2006. С. 220-222. Залогин Б.С., Косарев А.Н. Моря. М.: Мысль, 1999. 400 с. 
Ильям Л. В., Житина Л. С., Федоров В. Д. Фитопланктон Белого моря. М.: «Янус-К», 2003. $168 \mathrm{c}$.

Кадамова Н.А. Физико-географические аспекты природопользования в Белом море. Автореферат дис. ...канд. географ. наук. М., 2011. 175 с.

Котова Е.И., Красавина А.С., Соболевская А.П. Белое море. Качество морских вод по гидрохимическим показателям. Ежегодник 2015. Под ред. Коршенко А.Н. М.: «Наука», 2016. С. 104-109.

Кузнецов В.В. Белое море и биологические особенности его флоры и фауны. Изв. АН СССР, 1960. $322 \mathrm{c}$.

Леонов A.B. Моделирование природных процессов на основе имитационной гидроэкологической модели трансформации соединений C, N, P, Si: учебное пособие. Южно-Сахалинск: Изд-во СахГУ, 2012. 148 с.

Леонов А.В., Колтовская Е.В., Чичерина О.В. Биогидрохимический портрет Белого моря // Компьютерные исследования и моделирование. 2018. Т. 10. № 1. С. 125-160.

Леонов А.В., Семеняк Л.В., Чичерина О.В. Углеводороды в Белом море: их поступление и трансформация в морской среде в разных районах // Водные ресурсы. 2017. Т. 44. № 1. C. $38-62$.

Леонов А.В., Филатов Н.Н., Здоровеннов Р.Э., Здоровеннова Г.Э. Функционирование экосистемы Белого моря: исследование на основе математической модели трансформации органогенных веществ // Водные ресурсы. 2004. Т. 31. № 5. С. 556-575.

Леонов А.В., Филатов Н.Н., Здоровеннов Р.Э., Здоровеннова Г.Э. Математическое моделирование условий функционирование экосистемы губы Чупа Белого моря: трансформация органогенных веществ и биопродуктивность морской среды // Водные ресурсы. 2006. Т. 33. № 5. С. 589-614.

Леонов А.В., Филатов Н.Н., Чичерина О.В. Трансформация органогенных веществ в экосистеме Белого моря: оценка по результатам математического моделирования // Водные ресурсы. 2005. Т. 32. № 4. С. 435-451.

Леонов А.В., Чичерина О.В. Вынос биогенных веществ в Белое море с речным стоком // Водные ресурсы. 2004. Т. 31. № 2. С. 170-192.

Лисищын А.П. Процессы в водосборе Белого моря: подготовка, транспортировка и отложение осадочного материала, потоки вещества, концепция «живого водосбора». Система Белого моря. М.: Научный мир, 2010. Т. 1. С. 353- 455.

Моисеенко Т.И. Загрязнение поверхностных вод водосбора и ключевые антропогенно обусловленные процессы. Система Белого моря. М.: Научный мир, 2010. Т. 1. C. 301-333.

Надежин В.M. Характерные особенности гидрологического режима Белого моря // Тр. ПИНРО, 1966. Вып. 17. С. 237-248.

Невесский Е.Н., Медведев В.С., Калиненко В.В. Белое море. Седиментогенез и история развития в голоцене. М.: Наука, 1977. $236 \mathrm{c.}$

Океанографические условия и биологическая продуктивность Белого моря. Аннотированный атлас. Мурманск: ПИНРО, 1991. 115 с.

Толстиков А.В. Изменчивость температуры поверхностного слоя Белого моря. М.: ГЕОС, 2016. $212 \mathrm{c}$.

Экологический атлас России. М.: Карта, 2002. 128 с.

Ягов Г.В. Контроль содержания соединений азота при очистке сточных вод// Водоснабжение и санитарная техника. 2008. № 7. С. 45-52.

Meybeck M. Carbon, nitrogen, and phosphorus transport by world rivers // Am. J. Sci. 1982. Vol. 282. P. 401-450. 